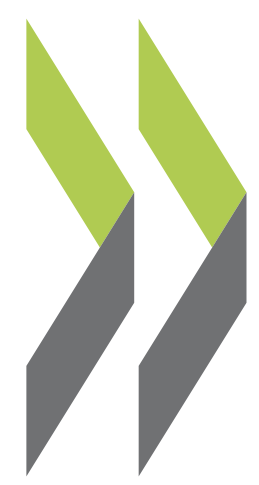

OECD Economics Department Working Papers No. 842

\author{
Limiting Long-Term \\ Unemployment and Non- \\ Participation in Sweden
}


Organisation de Coopération et de Développement Économiques

Organisation for Economic Co-operation and Development

09-Feb-2011

ECONOMICS DEPARTMENT

English, French

LIMITING LONG-TERM UNEMPLOYMENT AND NON-PARTICIPATION IN SWEDEN

ECONOMICS DEPARTMENT WORKING PAPER No. 842

By Niels-Jakob Harbo Hansen

All Economics Department Working papers are available through the OECD internet website at www.oecd.org/workingpapers 


\title{
ABSTRACT/RÉSUMÉ \\ Limiting Long-Term Unemployment and Non-Participation in Sweden
}

\begin{abstract}
After the onset of the crisis, unemployment in Sweden increased markedly, though much less than expected and than during the early 1990s, even as participation in the labour market held up well. The challenge going forward is to ensure that high unemployment does not become entrenched or leads to withdrawals from the labour force. The government has taken measures to mitigate this risk, particularly in the areas of job-search incentives and enrolment in education. Nevertheless, additional reforms are needed to ensure a sustained job-rich expansion. Such reforms should focus on increasing the flexibility of the labour market and strengthening job-search incentives further. This Working Paper relates to the 2011 OECD Economic Survey of Sweden (www.oecd.org/eco/surveys/Sweden).
\end{abstract}

JEL classification: J08; J30; J60; K31; H20

Keywords: Sweden; labour market dualism; employment protection legislation; minimum wage; labour cost; public employment services.

$* * * * * * * * * * * * * * * * * * * *$

\section{Limiter le Chômage de Longue Durée et la Non-Participation à l'Activité en Suède}

Après qu'a éclaté la crise, le chômage en Suède a augmenté fortement, bien que beaucoup moins que prévu et que pendant le début des années 90 , même si la participation au marché du travail s'est bien maintenue. Le défi pour l'avenir consistera à éviter que le haut niveau de chômage ne perdure ou ne conduise à des retraits de la vie active. Le gouvernement a pris des mesures pour atténuer ce risque, en particulier avec des incitations à la recherche d'emploi et en encourageant le recours à la formation. Néanmoins, d'autres réformes seront nécessaires pour garantir une croissance soutenue riche en emplois. Il faudrait s'attacher à accroitre la flexibilité du marché du travail et à renforcer davantage encore les incitations à la recherche d'emploi. Ce document se rapporte à l'Étude économique de la Suède de l'OCDE, 2011 (www.oecd.org/eco/etudes/suede).

Classification JEL : J08; J30; J60; K31; H20

Mots clés: Suède; dualisme du marché du travail; législation de protection d'emploi; salaire minimum ; coût du travail ; services publics de l'emploi.

\section{Copyright OECD 2010}

Application for permission to reproduce or translate all, or part of, this material should be made to: Head of Publications Service, OECD, 2 rue André-Pascal, 75775 Paris cedex 16, France. 


\section{TABLE OF CONTENTS}

Limiting long-term unemployment and non-participation in Sweden ..................................... 5

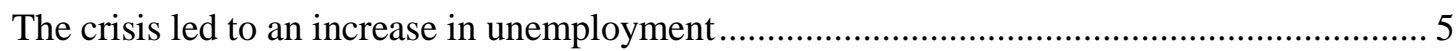

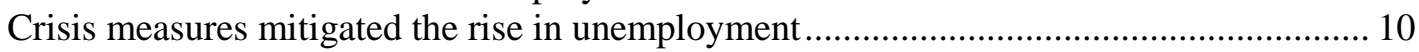

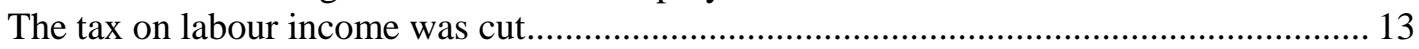

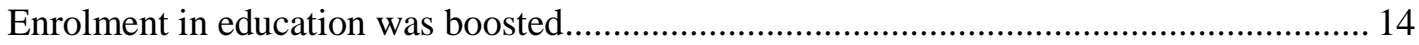

Active labour market policy relies heavily on subsidised employment ............................... 15

Additional reforms are needed to avoid lasting labour market scars ...................................... 18

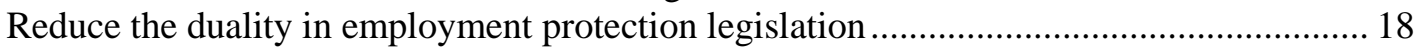

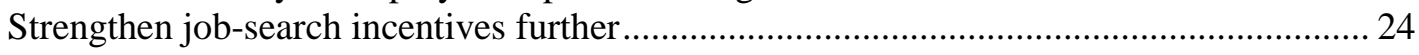

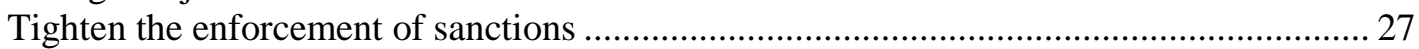

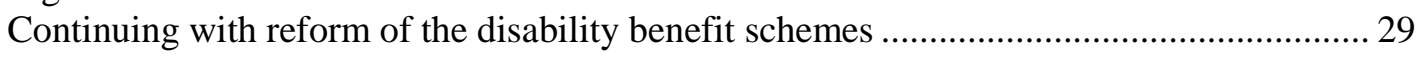

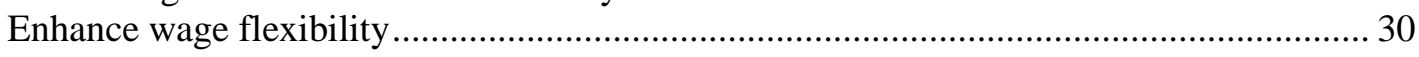

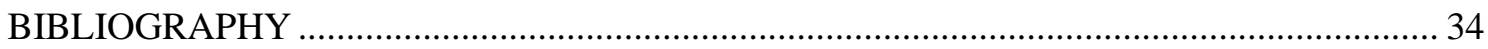

Annex 1. Unemployment benefits and active labour market policy programmes in Sweden..... 39

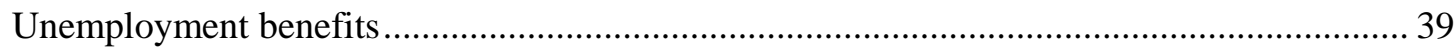

Job and Development Guarantee and the Job Guarantee for the Youth .................................. 39

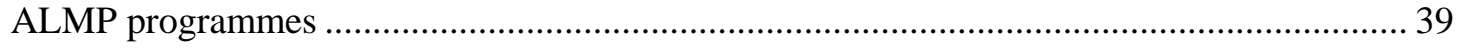

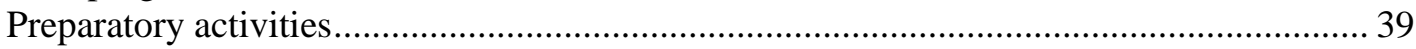

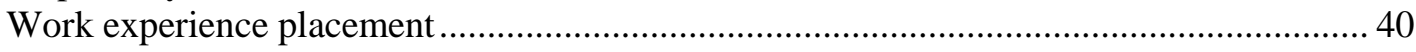

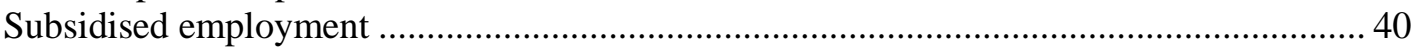

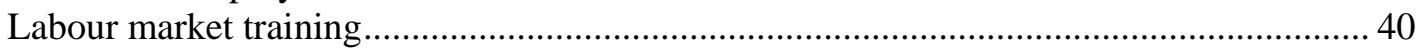

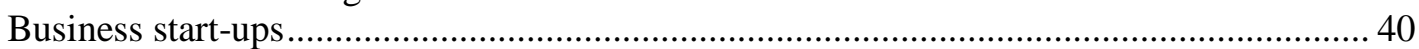

\section{Tables}

Table 1. Composition of participants in active labour market programmes ............................ 16

Table 2. Components of the EPL indicator for Sweden ......................................................... 22

\section{Figures}

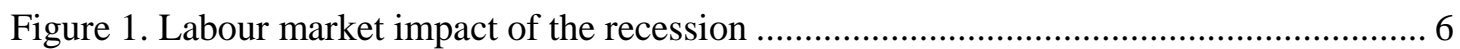

Figure 2. Comparison of the labour market in the recessions starting in 1990 and 2008 ......... 7

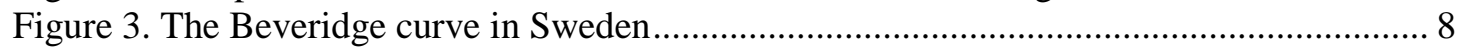

Figure 4. The effects of the recession across groups of workers ............................................. 8

Figure 5. Labour market adjustments during the recession .................................................... 9

Figure 6. Share of the working-age population receiving various types of income support ... 11

Figure 7. Discretionary labour market policy measures in response to the crisis.................... 11 


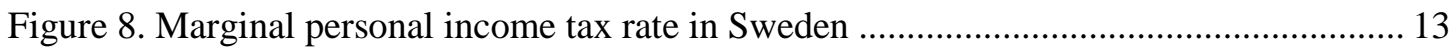

Figure 9. Additional spending on active labour market programmes in 2008-10 ................... 15

Figure 10. Transition rate from unemployment to Nystartsjobb .......................................... 17

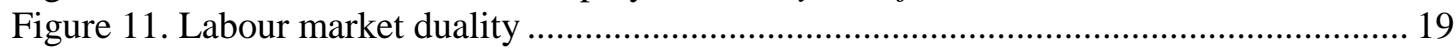

Figure 12. Reallocation of labour and employment protection legislation.............................. 20

Figure 13. Notice periods in OECD countries ........................................................................ 24

Figure 14. Work incentives for low-income persons, 2010 ............................................... 25

Figure 15. Marginal effective tax rate for a worker not eligible for unemployment benefits.. 26

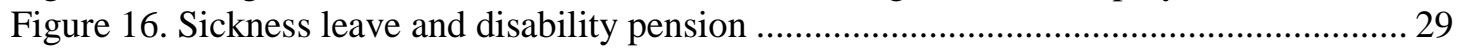

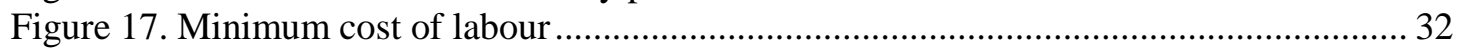

\section{Boxes}

Box 1. Comparison of the labour market in the recessions starting in 1990 and 2008 .............. 6

Box 2: Labour market measures taken in the budgets for 2009 and 2010 .............................. 12

Box 3: Employment protection legislation in selected other OECD countries.......................... 23

Box 4. Measuring the minimum cost of labour in Sweden.................................................... 31

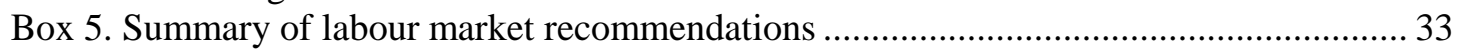


ECO/WKP(2011)11

\title{
LIMITING LONG-TERM UNEMPLOYMENT AND NON-PARTICIPATION IN SWEDEN
}

\author{
By Niels-Jakob Harbo Hansen ${ }^{1}$
}

As the crisis hit in 2008, employment and participation rates in Sweden were among the highest in the OECD. These good results can be partly attributed to the "Swedish model" in which social partners are responsible for wage-setting while the government supports job-losers with relatively generous social benefits and helps them back into work through extensive active labour market policies. Furthermore, after the early 1990s, several reforms scaled back benefit entitlements and raised incentives to look for a job. However, important challenges remain. The share of the population receiving incapacity benefits is among the largest in the OECD in spite of a marked decline in recent years. The government has introduced reforms to bring outsiders back into the labour market. An important challenge is to ensure the success of these reforms despite the impact of the crisis on the labour market. Furthermore, the labour market integration of vulnerable groups, notably youth and foreign-born workers, is relatively weak (Liebig, 2009; Scarpetta et al., 2010; OECD, 2008).

This working paper discusses the labour market policy challenges Sweden faces in the wake of the crisis. It first assesses how the labour market performed during the crisis, including a comparison with developments in other OECD countries and the recession in Sweden in the early 1990s. It then turns to the labour market policy measures taken in the face of the crisis and reviews how these need to be adjusted during the recovery. Finally, the paper discusses what additional structural measures the government can take to limit long-term unemployment and non-participation beyond the recovery.

\section{The crisis led to an increase in unemployment}

As the global recession deepened in 2008 the Swedish labour market deteriorated (Figure 1), but much less than during the early 1990s crisis (Box 1). In the early stages of the recession, companies mainly shed workers on temporary contracts, but subsequently dismissals of workers on regular contracts also picked up. ${ }^{2}$ Partly due to their reliance on temporary contracts, the youth and low-skilled were the most severely affected, as were the immigrants, in line with historical patterns. ${ }^{3}$ With employment shrinking and the labour force on a rising trend, unemployment rose markedly. Long-

1. Consultant to the OECD Economics Department (Email: nielsjakobharbo.hansen@iies.su.se). This paper is based on work originally prepared for the 2010 Economic Survey of Sweden published on 20 January 2011 under the authority of the Economic and Development Review Committee (EDRC) but also includes additional material. The author is very grateful for help, discussion and guidance from Henrik Braconier, Andrew Dean, Robert Ford, David Grubb, Jens-Christian Høj, Stéphanie Jamet, Vincent Koen, Peter Tergeist, Daniella Venn and Luke Willard. Per Skedinger is thanked for providing access to his data on Swedish wages. Fredrik Jansson-Dahlen is thanked for providing access to data on Nystartjobben. Thomas Chalaux is thanked for excellent statistical assistance and Pascal Halim for excellent editing support. The author retains full responsibility for errors and omissions.

2. Temporary employment (tidsbegränset anställda) started to fall already in November 2007 and declined $18 \%$ (seasonally adjusted by the Secretariat) towards its trough in November 2010. Regular employment (fast anställda) did not start to fall before October 2008 and only declined by $3.6 \%$ at its through in December 2009.

3. The business sensitivity of Swedish youth unemployment (aged 15-24) is 5.3 times larger than the sensitivity of prime age workers (aged 25-54) (OECD, 2009a). 
term unemployment shot up even faster as the outflow from unemployment also declined. However, Sweden was among the first countries to experience a rebound in employment.

Figure 1. Labour market impact of the recession ${ }^{1,2}$
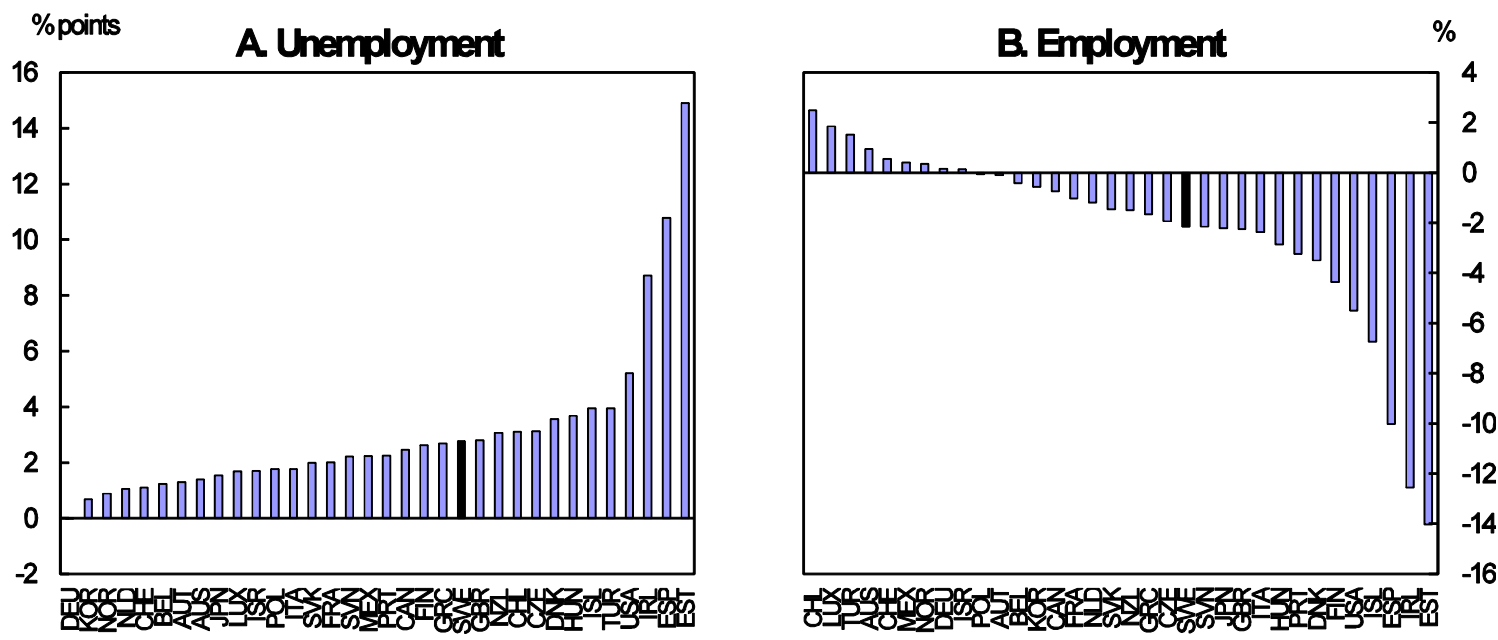

1. Impact from GDP peak to trough plus two quarters to account for lagged labour market adjustment.

2. For Greece and Iceland the period between 2008Q3 and 2009Q4 is shown because there is no trough plus two quarters in the GDP series. The recession shown for Norway is the one that has started in 2008. Australia and Poland did not have a recession in 2008-09 but are shown for comparison purposes over the period 2008Q3 to 2009Q4.

Source: OECD Analytical Database; OECD (2010c).

\section{Box 1. Comparison of the labour market in the recessions starting in 1990 and 2008}

The labour market impact of the crisis has been significantly less severe than that of the Swedish recession in the early 1990s (Figure 2). Employment dropped less, unemployment rose more slowly and labour force participation held up better. In addition the turnaround in employment has happened much faster.

At least two factors underpin these important differences. First, the sectoral composition of the latest recession was less labour intensive. While the drop in global demand mainly affected output in the Swedish manufacturing sector, the labour-intensive service sector was aided by the relatively muted drop in private consumption. This contrasts with the early 1990s, when the drop in private consumption was larger and lasted longer. Construction was also hit less than in the 1990s, as the impact on residential investment was smaller. Second, companies appear to have hoarded labour to a larger degree. This could reflect that the employers, so far correctly, considered the negative shock to be more temporary than in the 1990s.

It is still too early to conclude how the increase in cyclical unemployment will affect structural unemployment and participation. However, empirical studies suggest that the reforms implemented in Sweden since the 1990s will lessen the impact of the recession (Guichard and Rusticelli, 2010; Furceri and Mourougane, 2009). Product market reforms (Erlandsen and Lundsgaard, 2007) have enhanced the ability of the economy to create new jobs following the economic downturn, which can be expected to shorten the unemployment spell for job losers. Tax reforms have made work more attractive while reforms of the unemployment benefit system have shortened the effective duration of benefits and reduced replacement rates (OECD, 2007). In particular, the possibility of using training programmes to requalify for unemployment benefits was abolished in the 1990s. These reforms are also expected to mitigate the effect on long-term unemployment by increasing job losers' search intensity and their willingness to accept job offers. 
Figure 2. Comparison of the labour market in the recessions starting in 1990 and 2008
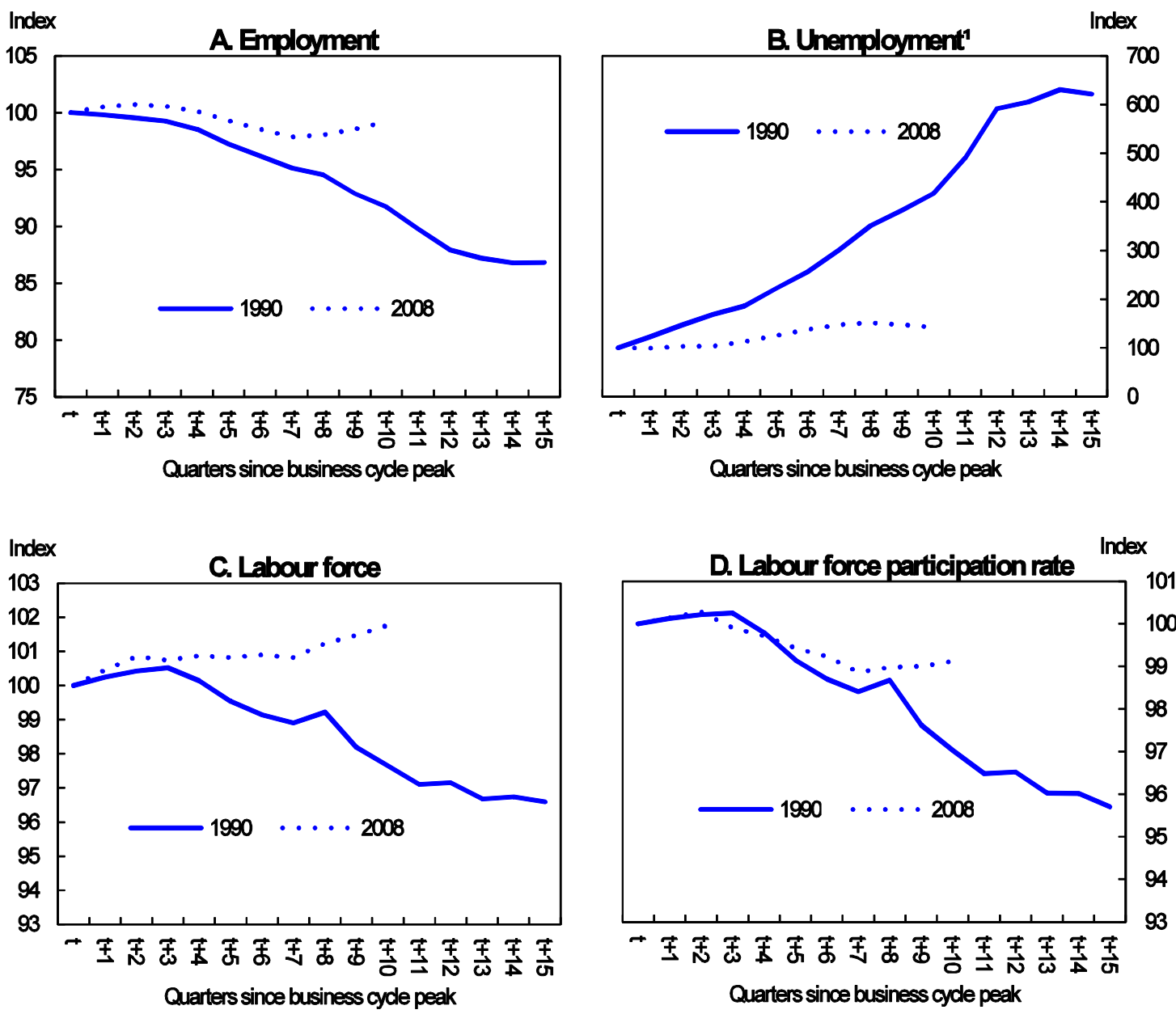

Source: OECD Analytical Database.

1. Unemployment among the 16-74 year olds in the civilian labour force.

Going forward, a main challenge will be to prevent the increase in cyclical unemployment becoming structural. The Swedish labour market crisis in the 1990s is a prominent example of a situation where weak labour demand kept up the number of long-term unemployed, leading to human capital depreciation and withdrawal from the labour force. A movement towards more passive labour market policies in the late $1980 \mathrm{~s}$, from a very active stance vis-à-vis other OECD countries, also contributed to this development. In particular, after 1986 participants in training programmes were entitled to a new period of UI benefits and a "carousel" effect of rotation between programme participation and passive benefits developed (Blöndal and Pearson, 1995). This effectively made unemployment benefits indefinite in duration. The scars from the crisis in the 1990s are still visible today as the unemployment rate never returned to its pre-crisis level (Figure 3). Since the 1990s, structural reforms have lowered the sensitivity of Swedish structural unemployment to changes in aggregate unemployment (Box 1), but risks remain high. In particular, recent inflows into unemployment were biased towards workers with low productivity who traditionally have difficulties in gaining a footing in the labour market. However, insofar as the increase in unemployment stemmed from recent reforms to boost participation, it may be temporary, at least to some extent. 
Figure 3. The Beveridge curve in Sweden

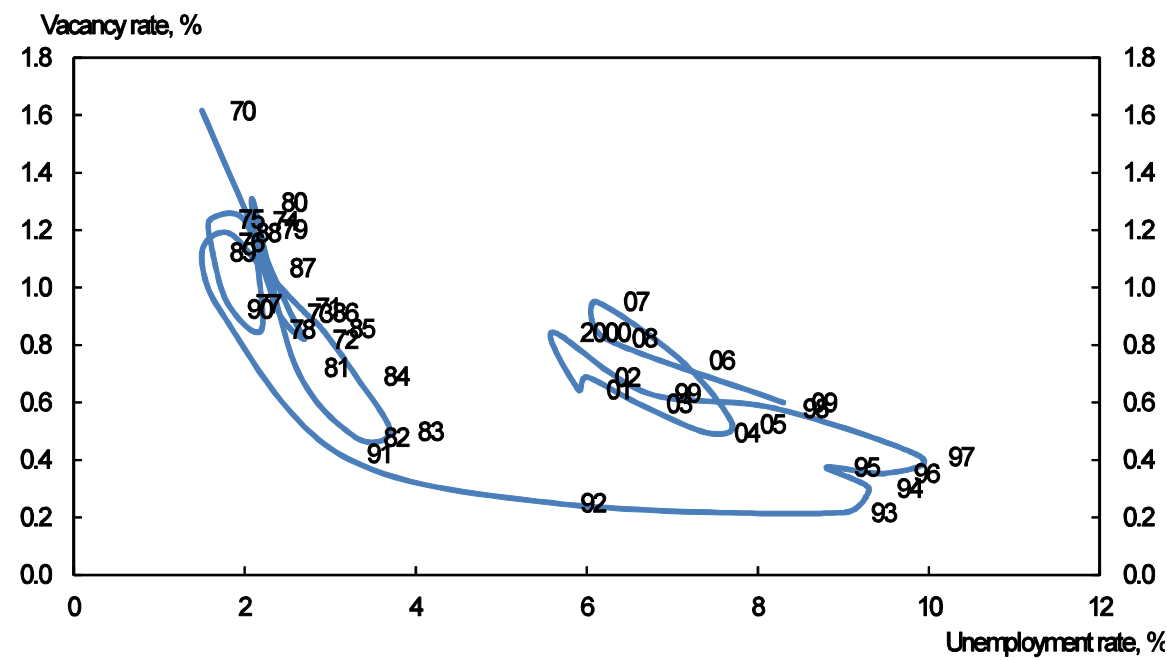

Source: OECD, Main Economic Indicators (2010).

Figure 4. The effects of the recession across groups of workers

Percentage change in employment by workforce group, 2008Q2 to 2009Q2

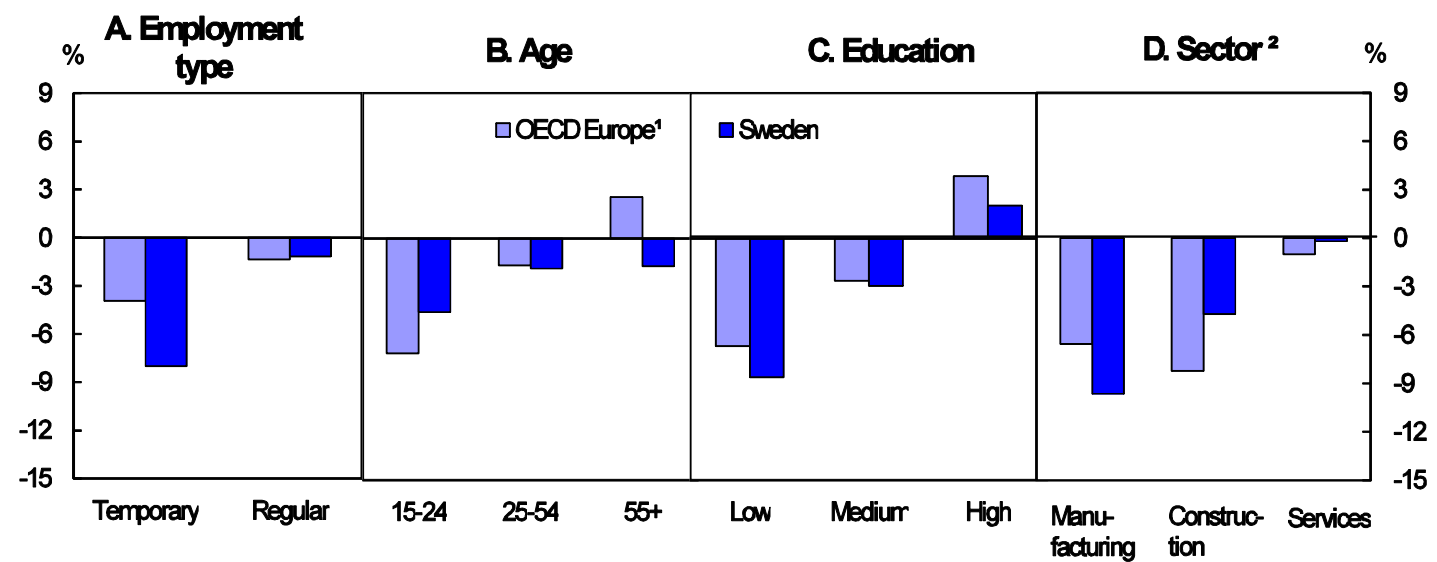

1. OECD Europe is an un-weighted average of all European OECD countries (excluding Slovakia). Turkey is also excluded for the composition by sector. Services are defined as: wholesale and retail trade; transportation and storage; accommodation and food service activities; information and communication; financial and insurance activities; real estate activities; professional, scientific and technical activities; arts, entertainment and recreation; other service activities.

2. Sector definitions follow the NACE rev. 2 definition.

Source: European Union Labour Force Survey (EULFS).

The labour market was mainly hit by the global crisis via the heavily export-dependent manufacturing sector. Most of the contraction in employment from 2007 to 2009 happened in this sector, with the declines being more muted in construction and especially services (Figure 5). Unlike many other countries, Sweden did not experience a housing market bust. Employment in construction and services was further helped by strong automatic stabilisers and discretionary stimulus measures, which supported domestic demand. Public sector employment did nevertheless also drop as local governments reduced the number of employees during the crisis. ${ }^{4}$

4. Employment in the municipalities fell by $2.4 \%$ from 2008 to 2009 . 
Figure 5. Labour market adjustments during the recession ${ }^{1}$
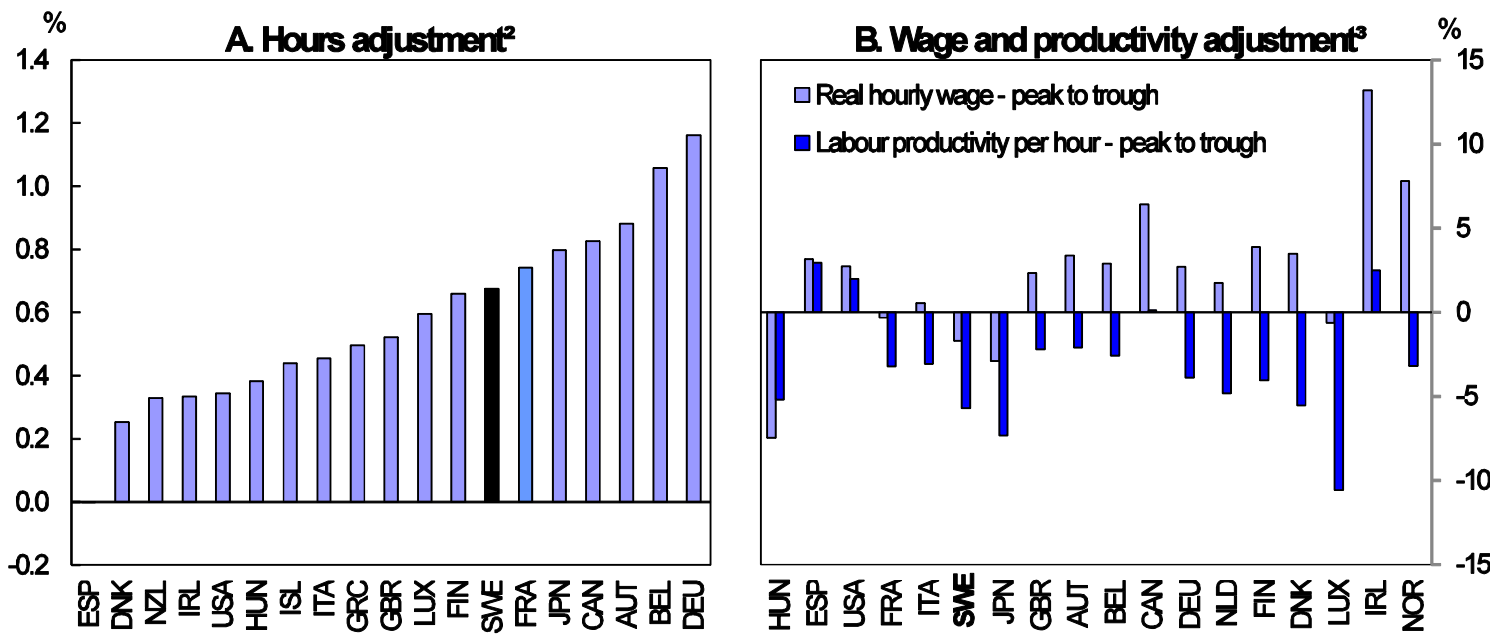

1. For Greece the period between $2008 \mathrm{Q} 3$ and $2009 \mathrm{Q} 4$ is shown because there is no trough in the GDP series. Australia and Poland did not have a recession in 2008-09 but are shown for comparison purposes over the period 2008Q3 to 2009Q2. The recession shown for Norway is the one that has started in 2008.

2. Share of the contribution of average hours to the total net change in labour input from real GDP peak to trough. A negative contribution arises when average hours rose during the recession.

3. Changes in real hourly wages and productivity per hour from the real GDP peak to trough.

Source: OECD Analytical database; OECD (2010c); various national sources for data on hours.

Downward adjustment of average hours lessened the impact of the crisis on employment, but not as much as in most OECD countries with short-time working schemes (Figure 5, Panel A; OECD, 2010d). In Sweden, a crisis agreement was reached in early 2009 between the social partners in the manufacturing sector (without any public financing), which helped limit job losses. This allowed wages at the local level to decrease up to $20 \%$ and working hours to fall substantially. In total, around $3 \%$ of all employees were affected by such local agreements in 2009 (Riksbank, 2010a), and according to labour unions and employers this reduced the rise in unemployment (IF-Metall, 2009).

Wage moderation also mitigated job losses. During the crisis, real hourly wages displayed flexibility (Figure 5, Panel B), as local wage negotiations served to contain wage inflation, especially in manufacturing. This moderation was all the more important as the earlier centrally-agreed wage increases for 2007-09 were relatively high (Riksbank, 2010a). Going forward, new wage agreements for 2010-12 covering 87\% of all wage earners will help keep wage inflation low and should therefore facilitate job creation. According to preliminary statistics from the National Mediation Office the centrally-agreed wage increases are $1.9 \%$ for 2010 and $1.7 \%$ for 2011 , as against $2.9 \%$ for 2009 . Recent wage agreements also incorporate lower wages for youths in the manufacturing sector as a response to the currently high rates of youth unemployment.

The central role of the manufacturing industry in the wage negotiations was an important driver of this moderate outcome. Since 1997, the negotiations are initially concluded in the manufacturing industry, and the sector therefore sets the norm for the subsequent negotiations in other sectors (Calmfors, 2008). ${ }^{5}$ Because of the disproportionate size of the shock in the manufacturing industry,

5. As established in the agreement within the manufacturing sector (Industriens samarbetsavtal) from 1997 and subsequently in agreements in other sectors, the manufacturing sector sets the norm for the rest of the economy (Calmfors, 2008). This is reflected in the fact that the sector is the first to conclude wage negotiations in the years of wage bargaining. 
this institutional setup contributed to achieving a moderate outcome of the central wage negotiations in 2010.

The crisis hit as Sweden was implementing reforms to boost employment and labour supply, including a reform of unemployment insurance and the introduction of an in-work tax credit. In the pre-crisis years these reforms, and a buoyant economy, increased employment and labour force participation. In the long run the reforms are expected to reduce structural unemployment by an estimated 0.5-2.0 percentage points (Konjunkturinstitutet, 2007; Forslund, 2008).

A longstanding problem for the Swedish labour market had been the large number of persons on incapacity benefits. The government had also undertaken reforms to promote this group's labour force participation (OECD, 2007, 2008). In 2008, new rules were put into force, tightening access to incapacity benefits and abolishing the temporary disability pension (OECD, 2009b). These reforms have contributed to both a lower inflow into and a higher outflow from incapacity benefits, causing the share of recipients in the working-age population to drop (Figure 6). The annual rate of outflows from disability pension has increased from $1 \%$ on average before the reforms to $1.9 \%$ in 2007 and $2.3 \%$ in 2008 (OECD, 2009b). However, empirical estimates suggest that, so far, most of those who have left the disability pension regime have moved into unemployment (Hägglund and Thoursie, 2010). ${ }^{6}$

As the labour market started to deteriorate in 2008, the continued implementation of these reforms, along with an increase in the working-age population, more than offset the labour force withdrawal that usually occurs during a recession. This increase in the labour force pushed unemployment up further, in addition to the direct effect of the crisis.

\section{Crisis measures mitigated the rise in unemployment}

The rise in unemployment was cushioned by the general macroeconomic stimulus measures described in OECD (2011), but also by a series of labour market initiatives (Box 2 and Figure 7). The latter aimed to help the unemployed get into employment by improving job-search incentives, stimulating labour demand and stepping up active labour market policies (ALMPs). The rise in unemployment was also limited by an extended access to the education system.

6. $84 \%$ of the workers who left the sickness and disability system primo 2010 due to phasing out of the temporary disability pension and the new upper limit for the duration of sickness benefits were at the end of February registered at the Public Employment Service. 
Figure 6. Share of the working-age population receiving various types of income support ${ }^{1}$

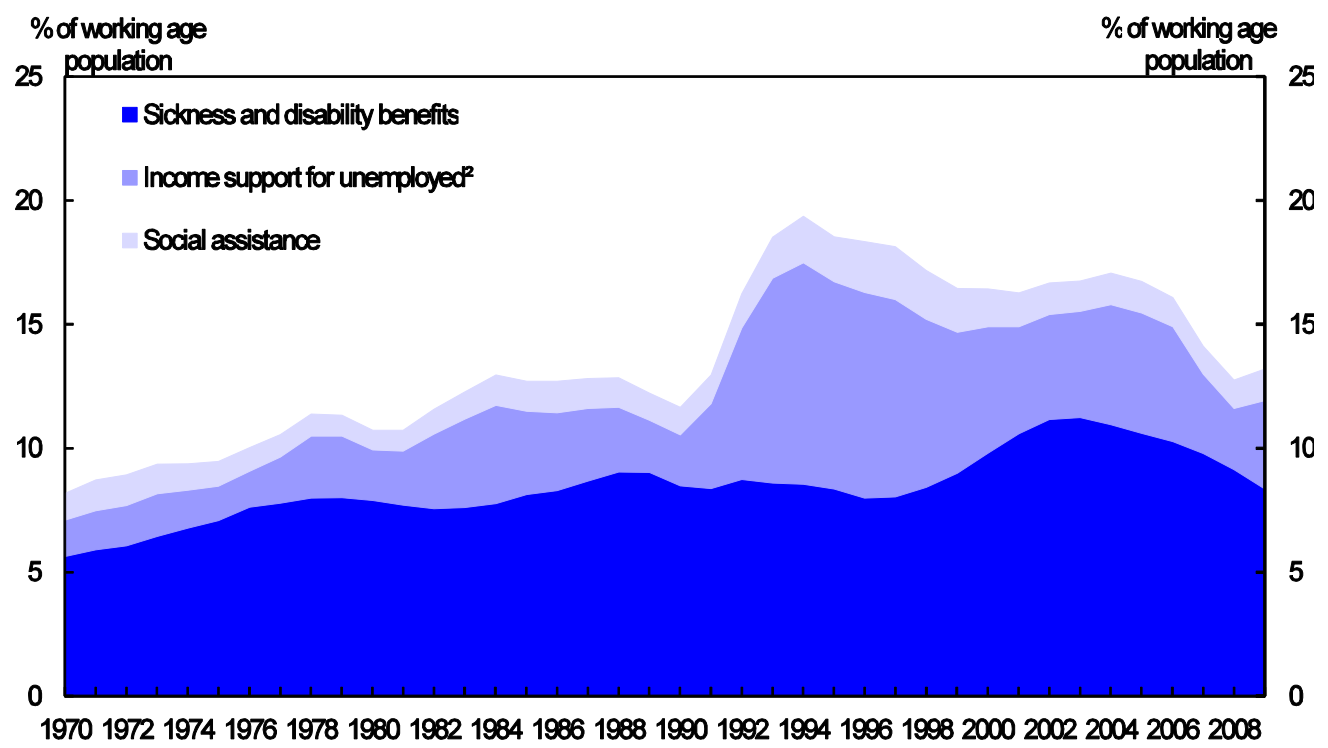

1. The number of recipients (calculated as full-year equivalents) as a percentage of the working-age population.

2. Includes recipients of unemployment benefits and support for unemployed in active labour market programmes. Source: Swedish Ministry of Finance; OECD Analytical database.

Figure 7. Discretionary labour market policy measures in response to the crisis Number of OECD countries ${ }^{1}$ that have taken different types of measures ${ }^{2}$

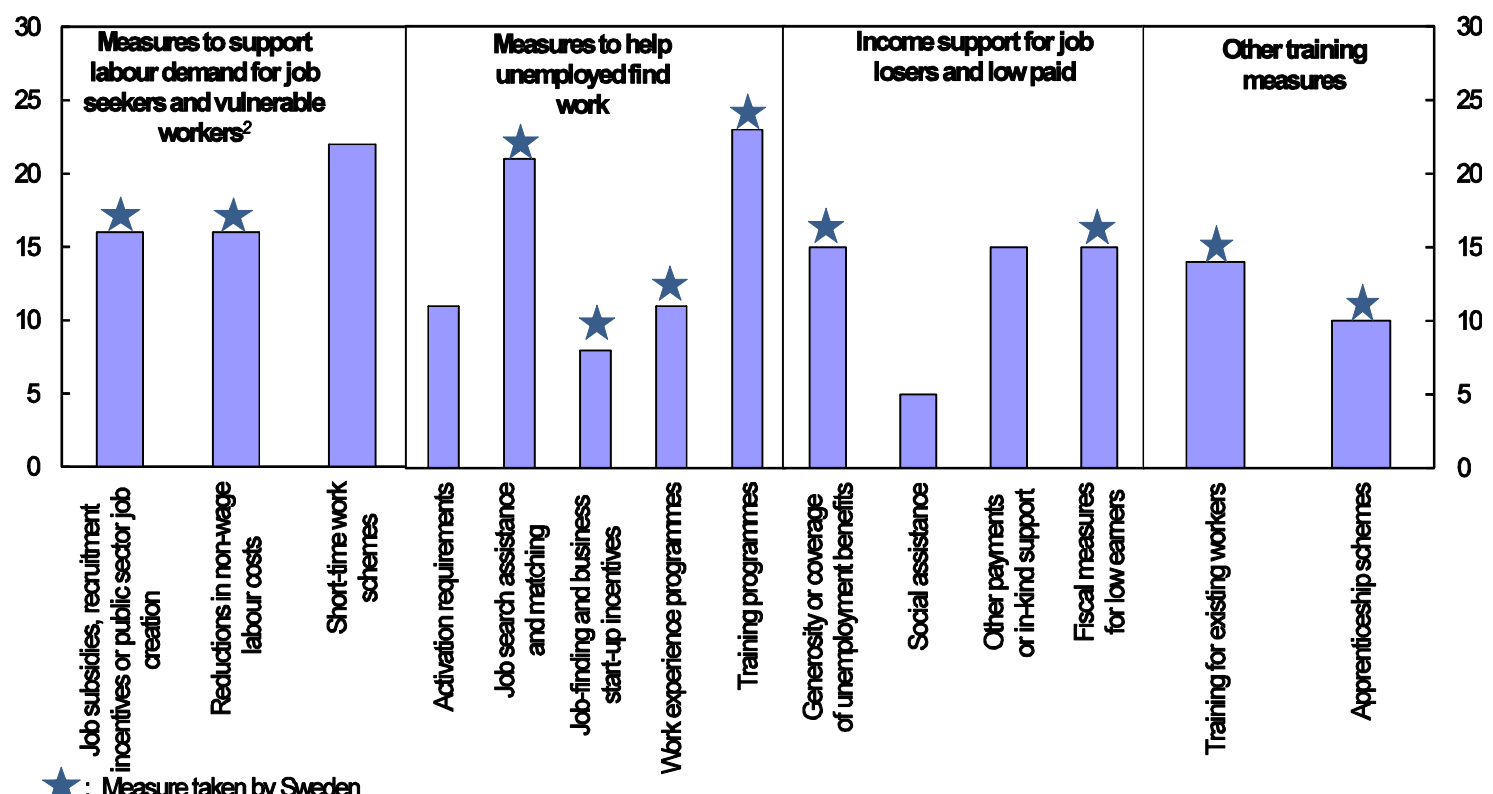

1. OECD countries except Iceland, Israel, Chile and Slovak Republic.

2. Does not include measures to increase aggregate labour demand such as fiscal stimulus packages.

Source: Response to OECD/EC questionnaire; OECD (2009a). 
ECO/WKP(2011)11

\section{Box 2: Labour market measures taken in the budgets for 2009 and 2010}

Description

Estimated ex-ante cost (\% of GDP) Duration

20092010

Labour demand

\begin{tabular}{|c|c|c|c|c|}
\hline \multirow{3}{*}{$\begin{array}{l}\text { Job subsidies, } \\
\text { recruitment incentives or } \\
\text { public sector job } \\
\text { creation }\end{array}$} & $\begin{array}{l}\text { Doubling of the subsidy for the employment incentive } \\
\text { scheme (Nystartsjobb). }\end{array}$ & $0.03 \%$ & $0.04 \%$ & Permanent \\
\hline & $\begin{array}{l}\text { The eligibility to the employment incentive scheme } \\
\text { (Nystartsjobb) is broadened from July } 2010 \text { to June } 2012 \\
\text { such that workers above age } 55 \text { qualify after a shorter } \\
\text { duration of unemployment. }\end{array}$ & & $0.002 \%$ & Temporary \\
\hline & $\begin{array}{l}\text { Increase in the grants to local governments to moderate the } \\
\text { fall in local government employment. }\end{array}$ & & $0.52 \%$ & Temporary $^{1}$ \\
\hline \multirow{2}{*}{$\begin{array}{l}\text { Reductions in non-wage } \\
\text { labour costs for new } \\
\text { hires }\end{array}$} & Reduction in employer social security contributions. $^{2}$ & $0.27 \%$ & $0.25 \%$ & Permanent \\
\hline & $\begin{array}{l}\text { Deferral of two months of employer social security } \\
\text { contributions and taxes for up to } 12 \text { months. This will be in } \\
\text { place until January } 2011 \text {. }\end{array}$ & $0.01 \%$ & $0.01 \%$ & Temporary \\
\hline \multirow[t]{2}{*}{ Other } & $\begin{array}{l}\text { A tax credit for repair and maintenance work was introduced } \\
\text { in } 2009 \text { to stimulate labour demand in the construction } \\
\text { sector. }\end{array}$ & $0.35 \%{ }^{3}$ & $0.36 \%$ & Permanent \\
\hline & $\begin{array}{l}\text { Additional government investment in infrastructure to } \\
\text { support employment in the construction sector. }\end{array}$ & $0.12 \%$ & $0.20 \%$ & Temporary \\
\hline \multicolumn{5}{|c|}{ Measures to help the unemployed find work } \\
\hline $\begin{array}{l}\text { Job search assistance } \\
\text { and matching }\end{array}$ & $\begin{array}{l}\text { Expanded job-search coaching (to a total of } 27500 \text { places } \\
\text { in } 2009 \text { and } 38000 \text { in 2010). }\end{array}$ & & & \\
\hline $\begin{array}{l}\text { Work experience } \\
\text { programmes }\end{array}$ & $\begin{array}{l}\text { Increase in number of places in work experience } \\
\text { programmes ( } 21600 \text { new places in } 2009 \text { and } 30000 \text { in } \\
2010) \text {. New activation scheme (Lyft) introduced in } 2010 \text { in } \\
\text { public sector and non-profit organisations ( } 40000 \text { new } \\
\text { places in 2010). }\end{array}$ & $0.11 \%$ & $0.12 \%$ & Temporary \\
\hline Training programmes & $\begin{array}{l}\text { Increase in the number of labour market training places } \\
(1000 \text { extra places in 2010). }\end{array}$ & & & \\
\hline $\begin{array}{l}\text { Job-finding and } \\
\text { business } \\
\text { start-up incentives }\end{array}$ & $\begin{array}{l}\text { Reduction in social security contributions for self-employed } \\
\text { and partners in partnerships. Increased coverage of } \\
\text { sickness insurance for entrepreneurs. }\end{array}$ & & $0.05 \%$ & Permanent \\
\hline \multicolumn{5}{|c|}{ Income support for job losers and low-income earners } \\
\hline $\begin{array}{l}\text { Generosity or coverage } \\
\text { of unemployment } \\
\text { benefits }\end{array}$ & $\begin{array}{l}\text { Reduction in length of membership of an unemployment } \\
\text { insurance fund required to draw on unemployment } \\
\text { insurance leading to an easing of the access to it. }\end{array}$ & $0.02 \%$ & $0.02 \%$ & Temporary \\
\hline $\begin{array}{l}\text { Fiscal measures raising } \\
\text { the net incomes of low } \\
\text { earners }\end{array}$ & $\begin{array}{l}\text { Introduction of a third step in the in-work tax credit in } \\
2009{ }^{2,4} \text { A fourth step in the tax credit was introduced in } \\
2010 \text {. }\end{array}$ & $0.48 \%$ & $0.77 \%$ & Permanent \\
\hline \multicolumn{5}{|l|}{ Other training measures } \\
\hline $\begin{array}{l}\text { Training for existing } \\
\text { workers }\end{array}$ & $\begin{array}{l}\text { In } 2009,1000 \text { additional places at vocational colleges and } \\
3600 \text { more in adult vocational training/adult education. } \\
\text { In both } 2010 \text { and } 2011,10000 \text { extra places at universities } \\
\text { and colleges, } 3000 \text { more at vocational colleges and } 10000\end{array}$ & $0.02 \%$ & $0.09 \%$ & Temporary $^{5}$ \\
\hline
\end{tabular}

more in adult vocational training/adult education.

Financial support for students has been increased.

Apprenticeship schemes $\begin{aligned} & \text { In 2009-10,1000 additional places at a pilot project for } \\ & \text { apprenticeships in upper secondary school. }\end{aligned}$

1. In addition to the temporary grant the local governments' resources are permanently increased by $0.2 \%$ of GDP, compared to the level in 2009 , from 2011 onwards.

2. Planned prior to the downturn.

3. Ex post cost.

4. The cost includes an increase of the threshold for the state tax.

5. The increase in financial support for students is permanent.

Source: Response to OECD/EC questionnaire; OECD (2009a); Swedish Government (2008a, 2009b, 2009c, 2009d, 2010a, 2010b); OECD Economic Outlook 87 database. 


\section{The tax on labour income was cut}

An important labour market measure taken during the crisis was the permanent expansion of the in-work tax credit (jobbskatteavdraget). It was extended in 2009 and again in 2010 at a total cost of $0.8 \%$ of GDP. The threshold for the state income tax, which accrues to the central government and implies a strong progression from above average earnings, was also increased. These measures cut the marginal tax rate for most income levels below 107\% of average full-time earnings (Figure 8). The average tax rate was reduced for all wage-earners, making it more attractive both to intensify job-search for the unemployed and to join the labour force for inactive people. In total these reforms are projected to increase employment by $0.6-0.8 \%$ according to estimates of the Swedish Ministry of Finance and the National Institute of Economic Studies (Swedish Fiscal Policy Council, 2010).

Taxation continues to impede the supply of hours for workers with earnings above $107 \%$ of the full-time average as they face very high marginal taxes compared with other OECD countries (OECD, 2010b). The government's intention to raise the lower threshold of the state income tax (as stated in the Budget Bill for 2011) would lower marginal taxes for workers with above-average earnings. However, the government could go even further and phase out the state income tax while raising taxes with less distortive effects on labour supply such as consumption and property taxes, as recommended in a previous OECD Economic Survey (OECD, 2008).

\section{Figure 8. Marginal personal income tax rate in Sweden ${ }^{1}$}

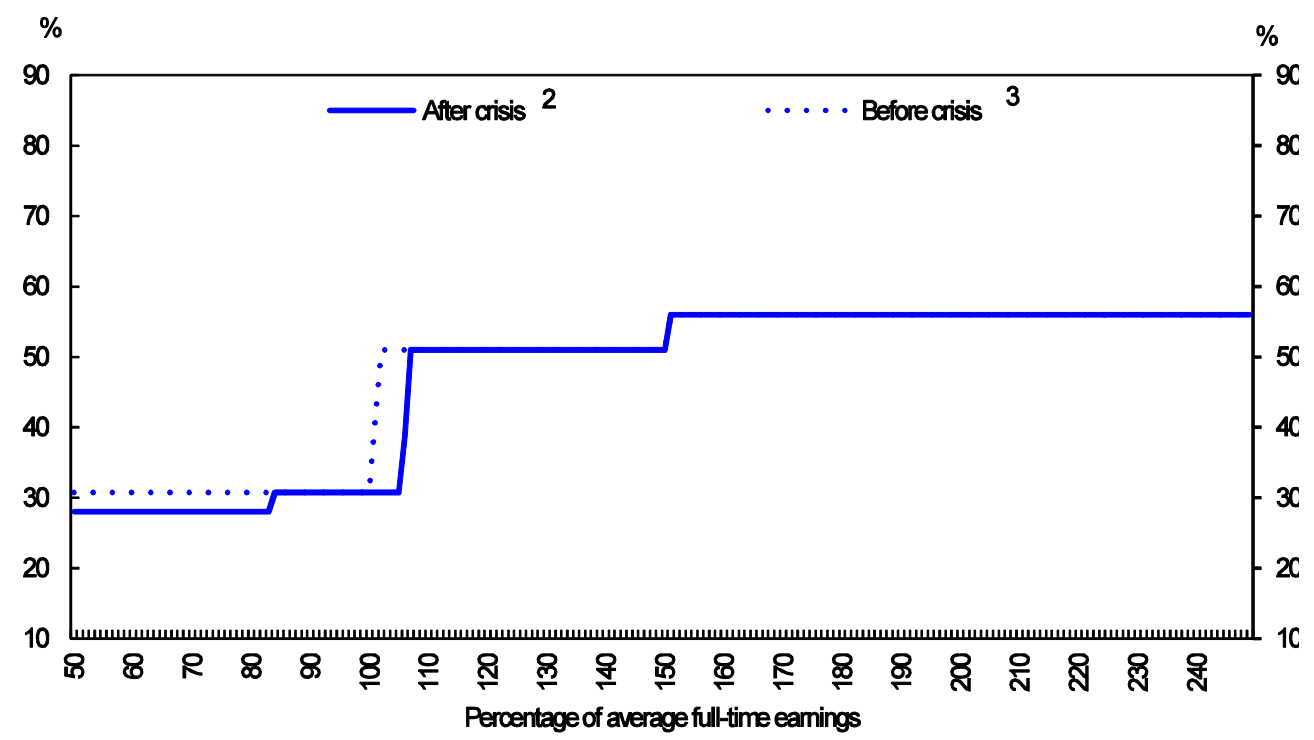

1. The marginal personal income tax rate is the part of an increase of gross wage earnings that is paid in personal income tax and social security contributions by the employee.

2. "Before crisis" shows the marginal personal income tax rate in 2008.

3. "After crisis" shows the marginal personal income tax rate in 2010.

Source: OECD, Taxing Wages 2008/2009 and calculations on the associated tax equations; Swedish Government (2008b, 2009a).

The Swedish in-work tax credit is not phased out as income rises, in contrast to most other OECD countries. It is fully phased in at $95 \%$ of full-time average earnings and not withdrawn for earnings above this threshold. As a result, it is expensive, with an ex-ante cost of $2.4 \%$ of GDP in 2010. The main reason for not phasing it out is to avoid very high marginal tax rates. Estimates show that phasing out the in-work tax credit would lower total hours significantly (Swedish Fiscal Policy Council, 2010; Bassanini et al., 1999). However, lower marginal tax rates above average income 
levels would allow to taper the in-work tax credit and to expand it for low-income earners, thereby boosting their job incentives.

\section{Enrolment in education was boosted}

Measures were also taken to enrol unemployed workers in education. The number of positions in the education system was temporarily and modestly expanded and the financial support available for students was increased. The share of the labour force enrolled in education has risen in the two years to $2010 .^{7}$ However, this is unlikely to be attributable only to government policies, as the number of students usually increases in an economic crisis, especially in countries like Sweden where education is easily accessible (Furceri and Zdzienicka, 2010; Fredriksson, 1997).

The strategy to boost the educational attainment of the unemployed, in response to the crisis, was warranted. Workers with low education attainment were severely hit by the drop in employment (Figure 4), and the recession was an opportunity to provide them with the necessary education to (re)gain footing in the labour market. In particular, education can help job-losers who are required to change occupation or sectors due to structural changes following the recession (OECD, 2009a). The higher intake into the education system therefore has the potential to bring down structural unemployment and lift participation rates in the long run. In this regard, the expansion of vocational training and apprenticeship schemes is a step in the right direction.

However, implementing such a "skills first, work later" strategy is difficult and international evidence on its effectiveness is mixed (Scarpetta et al., 2010). For Sweden, a number of risks stand out:

- A challenge will be to maintain the quality of education as the stock of students is expanded. Hence, careful evaluation of the impact on the performance of the education system is needed, as is indeed proposed in the Budget Bill for 2011. To the extent that the government uses private providers, it is important to design contracts in a manner that rewards good outcomes and minimises the disincentive to enrol weak clients and manipulate outcome indicators (OECD, 2005).

- As students may prefer to finish their programmes before entering the labour market, it could be more difficult for companies to hire workers with the necessary skills during the early stages of the recovery. This risk is amplified by the government's decision to scale up the financial support for students, which makes it more attractive for them to prolong studies rather than enter the labour force. A system of tuition fees with an expansion of government loans for students to finance tuition fees, as recommended in a previous OECD Economic Survey (OECD, 2008), would increase student incentives to enter the labour market when job opportunities reappear. Alternatively, the financial incentives underpinning the existing study support scheme could be improved.

- To ensure the success of vocational education measures it is important that programmes match labour market needs. The administration of vocational education is shared between the national agency for Higher Vocational Education (Myndigheten för Yrkeshögskolan) and local governments. The latter are well placed to know the needs of the labour market locally but do not internalise the need for specific skills in other regions. The introduction of tuition fees at the post-secondary level would be one way to give a stronger market signal for vocational education providers to offer programmes in high demand and for students to choose the programmes that will improve their employability the most. Moreover, the publicly available information on the performance of various programmes needs to be extended. The national

7. The share of full-time students in the working-age population increased by 0.7 percentage points from February 2008 to February 2010. . 
agency for Higher Vocational Education could be tasked to define and publish performance indicators.

- Experience from other OECD countries shows the importance of providing alternation between studies and on-the-job training to make sure that vocational education leads to employment for students (Scarpetta et al., 2010). On-the-job training is an important element of vocational education organised at the national level, and the government has recently extended the use of apprentice programmes in upper secondary school. However, local governments have no obligation to provide on-the-job experience in their programmes.

\section{Active labour market policy relies heavily on subsidised employment}

Sweden was among the countries that ramped up ALMP expenditures the most during the crisis (Figure 9). This came on top of a level that was among the highest in the OECD before the crisis (1.1\% of GDP in 2007). ALMP expenditures in Sweden are heavily tilted towards subsidised employment measures (with a share of $59 \%,{ }^{8}$ compared to an OECD average of $31 \%$ and to an average of $40 \%$ in Denmark, Finland and Norway). On the other hand the share of expenditures used on training is only $7 \%$, which is significantly lower than the average in the OECD (25\%) and in the other Nordics (30\%). The distribution of expenditures shapes the composition of participants in ALMP programmes: $90 \%$ are enrolled in subsidised employment, while only $8 \%$ are enrolled in training measures (Table 1).

Figure 9. Additional spending on active labour market programmes in 2008-10

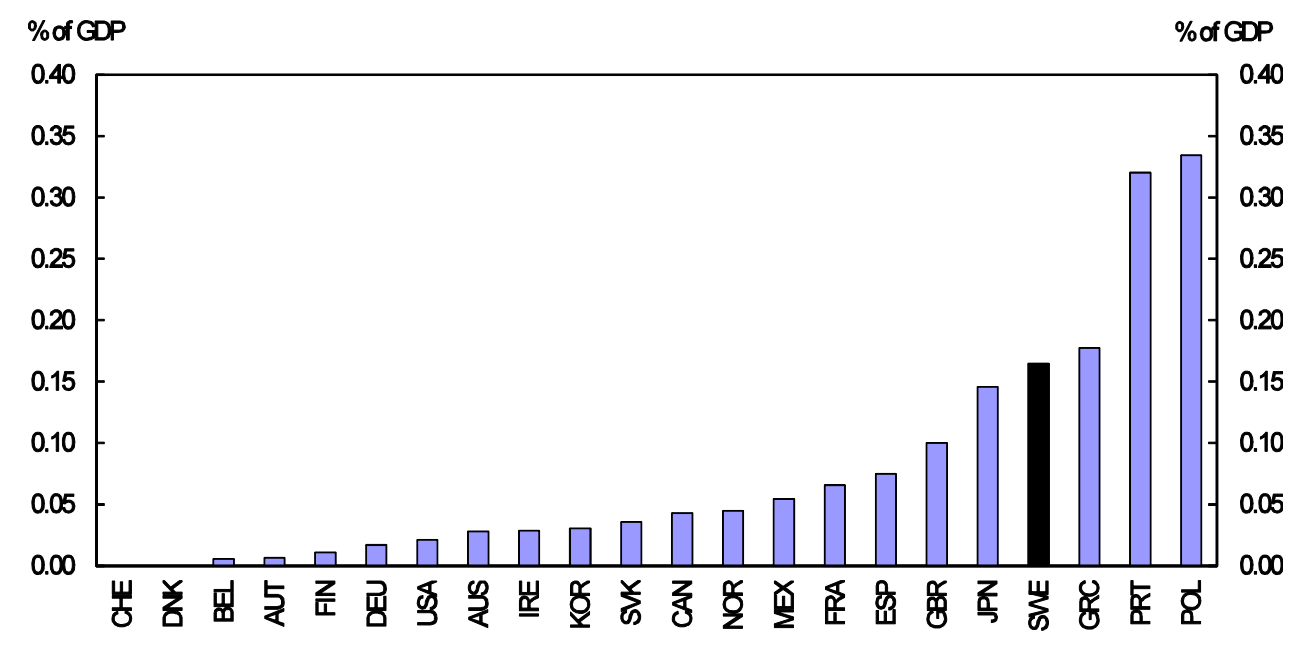

1. Average annual planned additional expenditure for 2008-10.

Source: OECD (2009a); OECD Labour Market Programmes Database.

In spite of the up-scaling of resources, the Public Employment Service (PES) experienced problems in ensuring the intended level of activation among the unemployed. Workers were referred to the mandatory Job- and Development Guarantee (Annex 1) after an unemployment spell of 60 weeks (only 12 weeks for youth), and by August 2010 the share of the labour force enrolled in the scheme was $2.4 \%$ (including the Job Guarantee for the Youth). However, enrolment in the scheme did not ensure intervention. A study finds that within the first 120 weeks after enrolment $89 \%$ of the participants are not "sufficiently" engaged in activation and job-search activities, meaning that these take up less than $75 \%$ of their usual working hours, and $65 \%$ of the participants are engaged less than 10 hours per week or not at all (Martinson and Sibbmark, 2010).

8. This covers employment incentive schemes, subsidised employment and rehabilitation. 
The lack of activation was partly caused by problems in securing the planned number of work experience placements (Riksrevisionen, 2009c), but also by the government's decision to keep the volume of labour market training programmes at a low level. These programmes had been scaled down markedly since the 1990s and, by 2008, Sweden was among the OECD countries with the lowest use of labour market training, although this should be seen in light of the decision to scale up volumes in the education system. Such a strategy was partly warranted as the Swedish experience with large volumes of institutional labour market training programmes in the 1990s yielded poor results in providing participants with regular employment (Calmfors et al., 2001). However, in countries like Sweden where the obligation to accept a job once enrolled in ALMPs is strong, ALMPs may act as a threat and may lead the unemployed to lower their reservation wage to find a job before enrolment (Rosholm and Svarer, 2004). Moreover, the low volumes of labour market training could create problems in identifying the unemployed who would benefit the most from these programmes as some unemployed may enrol in general education although they would need some more specific training.

Table 1. Composition of participants in active labour market programmes ${ }^{1,2}$ As of $2008, \%$

\begin{tabular}{|c|c|c|c|c|c|c|}
\hline & Training² & $\begin{array}{c}\text { Employment } \\
\text { incentives }^{3}\end{array}$ & $\begin{array}{c}\text { Supported } \\
\text { employment } \\
\text { and } \\
\text { rehabilitation }\end{array}$ & $\begin{array}{l}\text { Direct job } \\
\text { creation }\end{array}$ & $\begin{array}{c}\text { Start-up } \\
\text { incentives }\end{array}$ & $\begin{array}{c}\text { Job rotation } \\
\text { and job } \\
\text { sharing }\end{array}$ \\
\hline SVK & 1.5 & 10.9 & 2.1 & 62.5 & 23.0 & 0.0 \\
\hline LUX & 5.4 & 83.3 & 0.3 & 11.0 & 0.0 & 0.0 \\
\hline AUS & 6.6 & 0.0 & 73.0 & 20.4 & 0.0 & 0.0 \\
\hline SWE & 7.6 & 61.7 & 28.5 & 0.0 & 2.2 & 0.0 \\
\hline ESP & 8.6 & 71.8 & 2.1 & 0.0 & 14.2 & 3.4 \\
\hline CZE & 9.7 & 15.1 & 59.1 & 8.6 & 7.5 & 0.0 \\
\hline POL & 12.2 & 17.2 & 68.2 & 1.5 & 0.9 & 0.0 \\
\hline BEL & 21.1 & 41.8 & 7.3 & 29.4 & 0.3 & 0.0 \\
\hline GBR & 23.3 & 50.0 & 16.7 & 10.0 & 0.0 & 0.0 \\
\hline HUN & 24.1 & 51.9 & 0.0 & 19.8 & 4.3 & 0.0 \\
\hline $\mathrm{CHE}$ & 28.4 & 25.8 & 45.4 & 0.0 & 0.5 & 0.0 \\
\hline PRT & 30.1 & 50.0 & 3.7 & 12.5 & 3.7 & 0.0 \\
\hline GRE & 33.3 & 52.9 & 0.0 & 2.3 & 11.5 & 0.0 \\
\hline DNK & 40.9 & 15.2 & 43.9 & 0.0 & 0.0 & 0.0 \\
\hline NLD & 43.9 & 0.0 & 46.3 & 9.9 & 0.0 & 0.0 \\
\hline IRE & 48.3 & 6.2 & 4.7 & 34.3 & 6.5 & 0.0 \\
\hline FIN & 49.9 & 15.1 & 8.9 & 12.8 & 4.7 & 8.6 \\
\hline NZL & 50.2 & 0.0 & 49.8 & 0.0 & 0.0 & 0.0 \\
\hline DEU & 52.2 & 12.1 & 3.0 & 21.2 & 11.6 & 0.0 \\
\hline NOR & 53.3 & 8.9 & 25.2 & 12.1 & 0.5 & 0.0 \\
\hline FRA & 54.3 & 0.0 & 12.4 & 21.4 & 11.9 & 0.0 \\
\hline ITA & 54.8 & 41.9 & 0.0 & 1.5 & 0.3 & 1.4 \\
\hline AUT & 58.1 & 35.5 & 1.2 & 3.8 & 1.4 & 0.0 \\
\hline CAN & 86.2 & 6.1 & 0.0 & 2.2 & 5.5 & 0.0 \\
\hline
\end{tabular}

1. Training includes: institutional training; workplace training; integrated training; special support for apprenticeships.

2. Employment incentives include work experience placements in Sweden.

Source: OECD Labour Market Programmes Database.

The government also scaled up the employment incentive scheme (Nystartsjobb) (Annex 1). In 2009 the subsidy to employers was doubled, and in 2010 the group of eligible workers was 
temporarily expanded. By August 2010, 0.6\% of the labour force was enrolled in this scheme. As this scheme has substantial displacement effects, it is important that it targets those workers who are hardest to place (Lundin and Liljeberg, 2008). ${ }^{9}$ However, the probability of enrolment into the scheme is relatively high for the unemployed who just meet the minimum requirements for unemployment duration, but declines for unemployed with longer durations (Figure 10). Moreover, few workers with a prior history of sickness are enrolled (Hägglund and Thoursie, 2010). Hence, the government could consider narrowing the scope of the scheme to try to better target the unemployed most in need of help.

Figure 10: Transition rate from unemployment to Nystartsjobb

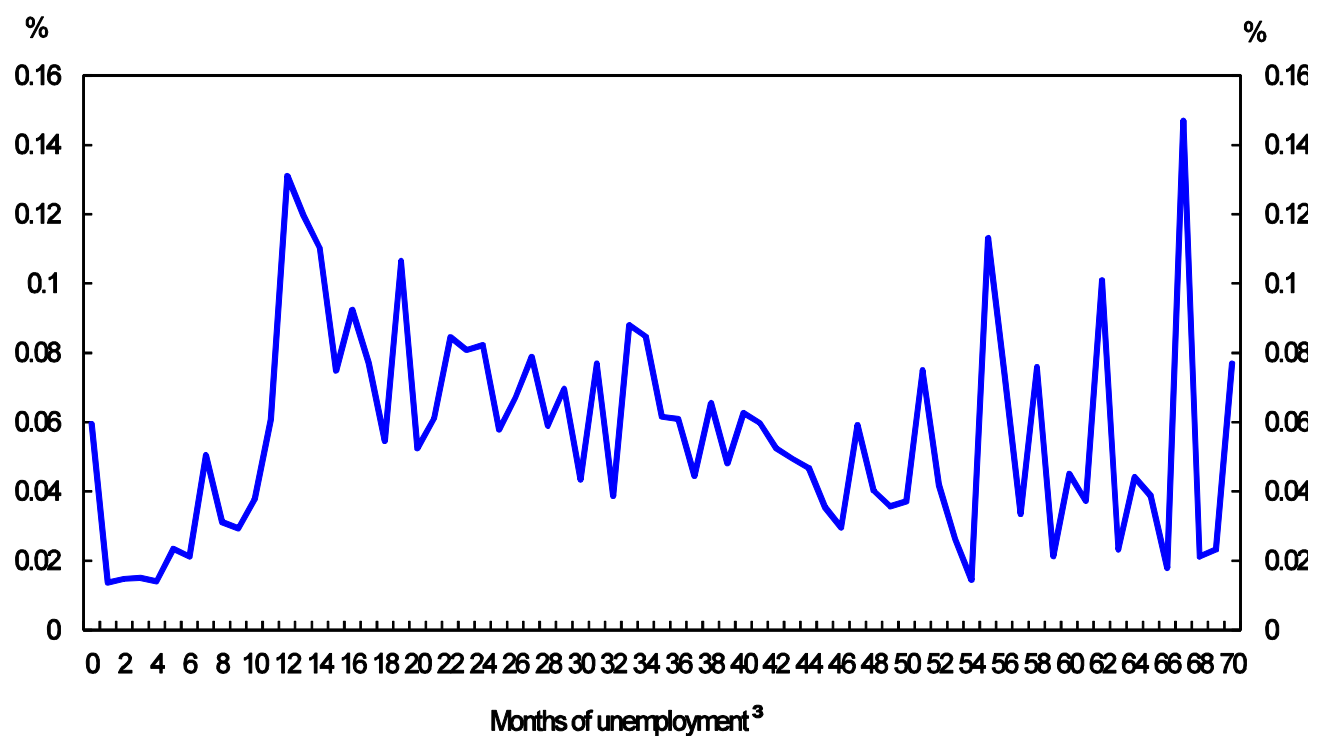

1. The transition rate is the share of unemployed that moves from unemployment into the employment incentive scheme, Nystartsjobb.

2. The transition rate for each month has been constructed by averaging over the observations of rates in that month.

3. Months of unemployment include time in the Job- and Development Guarantee and Job- and Development Guarantee for the Youth.

Source: Public Employment Service Sweden.

The government has implemented a new subsidised employment measure for the long-term unemployed. From 2009, the unemployed with a spell of unemployment above 130 weeks are referred to mandatory work experience placement, mainly in the public sector or in non-profit organisations, where no wages or contributions are paid by the employer (Annex 1).$^{10}$ In the past such activities have proved rather unsuccessful in providing workers with regular employment (OECD, 2010c), and instead risk increasing the number of workers in labour market programmes permanently (OECD, 2009c). However, the schemes can be useful in keeping the unemployed attached to the labour market during a period of high unemployment. Given the continued inflow into the labour force of workers from the incapacity schemes it seems reasonable to keep the work experience placement scheme in

9. . A study by Lundin and Liljeberg (2008) suggests that 50-70\% of the jobs created by the employment incentive programme crowd out regular employment.

10. The third phase of the Job- and Development guarantee was implemented in 2009 (Arbetsförmedlingen (2009), which according to the design of the Swedish ALMP implies that the unemployed are referred to mandatory subsidised employment after 130 weeks of unemployment. 
place in the early stage of the economic recovery. But as labour market conditions improve, subsidised employment measures ought to be downsized and workers moved to training programmes and jobsearch. The government is taking steps in this direction, with work experience programmes set to be scaled down as the labour market recovers.

To better target ALMP resources, statistical tools could be helpful. While some unemployed need training to find employment, job-search requirements backed with credible sanctions are sufficient for others. Therefore, the government should step up its efforts to identify the unemployed with a high risk of becoming long-term unemployed, and refer them to mandatory intervention as quickly as possible. In this regard, greater use of the statistical profiling tool could help the PES identify the short-term unemployed with the highest potential gain from early intervention, provided this tool is carefully designed (Frölich et al., 2004; Bennmarker et al., 2007; Tergeist and Grubb, 2006). Steps have been taken in this direction: a pilot programme has been completed, and the PES is currently working towards national implementation.

\section{Additional reforms are needed to avoid lasting labour market scars}

Additional reforms are required to avoid a long-lasting increase in unemployment and to extend labour market participation even further. They include reducing the duality in employment protection legislation (EPL), improving job-search incentive further and increasing the flexibility of labour costs at the bottom of the wage distribution. Going forward, as the population ages, such measures may also be important for the viability of the Swedish welfare model (Andersen et al., 2007).

\section{Reduce the duality in employment protection legislation}

The Swedish labour market model relies to a large extent on social partners' involvement through collective agreements. This allows accommodation to macroeconomic shocks and sectoral idiosyncrasies and changes, while providing workers with adequate security. Against this backdrop, Sweden is the OECD country with the starkest asymmetry in EPL between regular and temporary contracts (Figure 11, Panel A), reflecting high protection for workers with regular contracts and low protection for those on temporary contracts. ${ }^{11}$ This is a result of several reforms to lower EPL on temporary contracts since the 1990 s, which were not matched by measures regarding regular employment. The latest one, in 2007, increased the maximum duration for most kinds of fixed-term contracts to two years (OECD, 2007).

11. The strict EPL for regular contracts is also reflected in the Doing Business indicator from the World Bank, where Sweden is assessed to be among the OECD countries with the least degree of flexibility in the regulation of hiring, working hours and redundancies (World Bank, 2010). 
Figure 11. Labour market duality
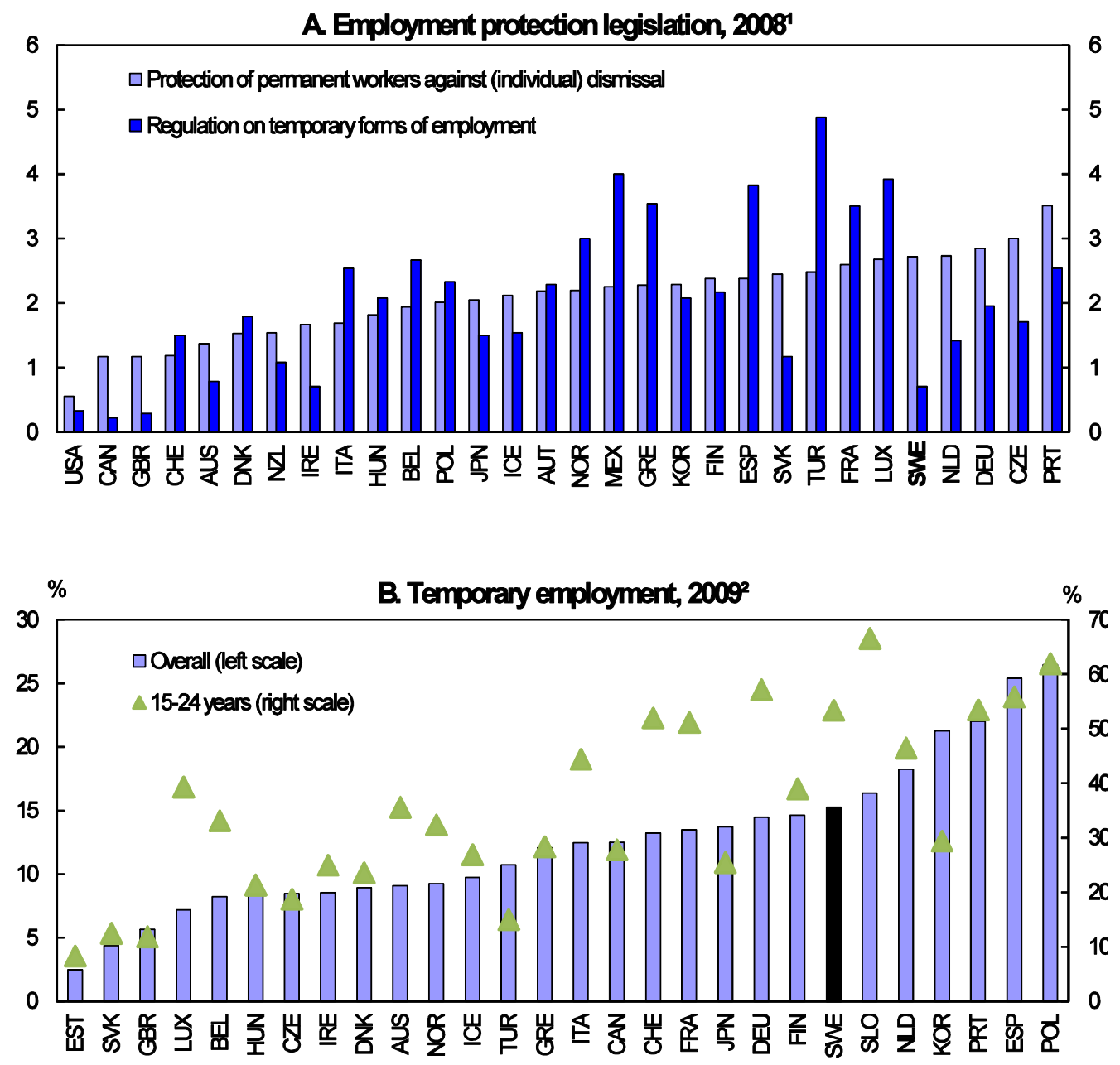

1. OECD indicator for strictness of employment protection legislation. Index scale is 0 to 6 , from least to most restrictive.

2. The incidence of temporary employment as a share of total dependent employment.

Source: OECD, Employment Protection Database; OECD, Labour Force Database.

The bifurcation in legislation has contributed to a significant rise in the share of temporary workers. From a level around the OECD average of $10 \%$ (Booth et al., 2002) in 1990, it has increased to over $15 \%$ in 2009 , well exceeding the OECD average of just above $11 \%$ (Figure 11, Panel B). This is in line with the experience of other OECD countries that pursued a similar deregulation of temporary employment while leaving the regulation of regular contracts unchanged (OECD, 2004). The increase in temporary contracts is welcome to the extent it enhances the flexibility of the labour market and of the economy as a whole. However, the failure to ease regulations on regular contract and thereby to lower the duality in legislation tends to have a number of adverse effects:

- $\quad$ Strict EPL for regular contracts protects existing jobs. During the recovery this could also hamper the reallocation of labour towards more productive activities. In this regard it is striking that labour reallocation is low in Sweden, like in other countries with strict EPL for regular contracts (Figure 12). Most empirical studies find a negative effect of EPL on job 
reallocation, ${ }^{12}$ which may help explain why countries with strict EPL experience a larger increase in structural unemployment following a severe recession (Furceri and Mourougane, 2009).

- $\quad$ EPL may lead to higher sickness absence, as witnessed in Sweden (see Skedinger (2010) for a survey). Higher employment protection reduces the risk of being fired and, therefore, the cost of absenteeism for workers (Arai and Thoursie, 2005). In addition, lower EPL is found to make employers less reluctant to hire workers with a history of sickness absence as the cost of dismissing them at a later stage is lower (Lindbeck et al., 2006).

- Workers on temporary contracts are largely on the margin of the labour market, notably the youth and low-skilled (OECD, 2002). This group has much to gain from on-the-job training, but evidence from Sweden shows that employers provide less training to temporary workers (Wallette, 2005). This undermines the ability of weaker groups to increase their productivity and thereby economy-wide productivity.

Figure 12: Reallocation of labour and employment protection legislation
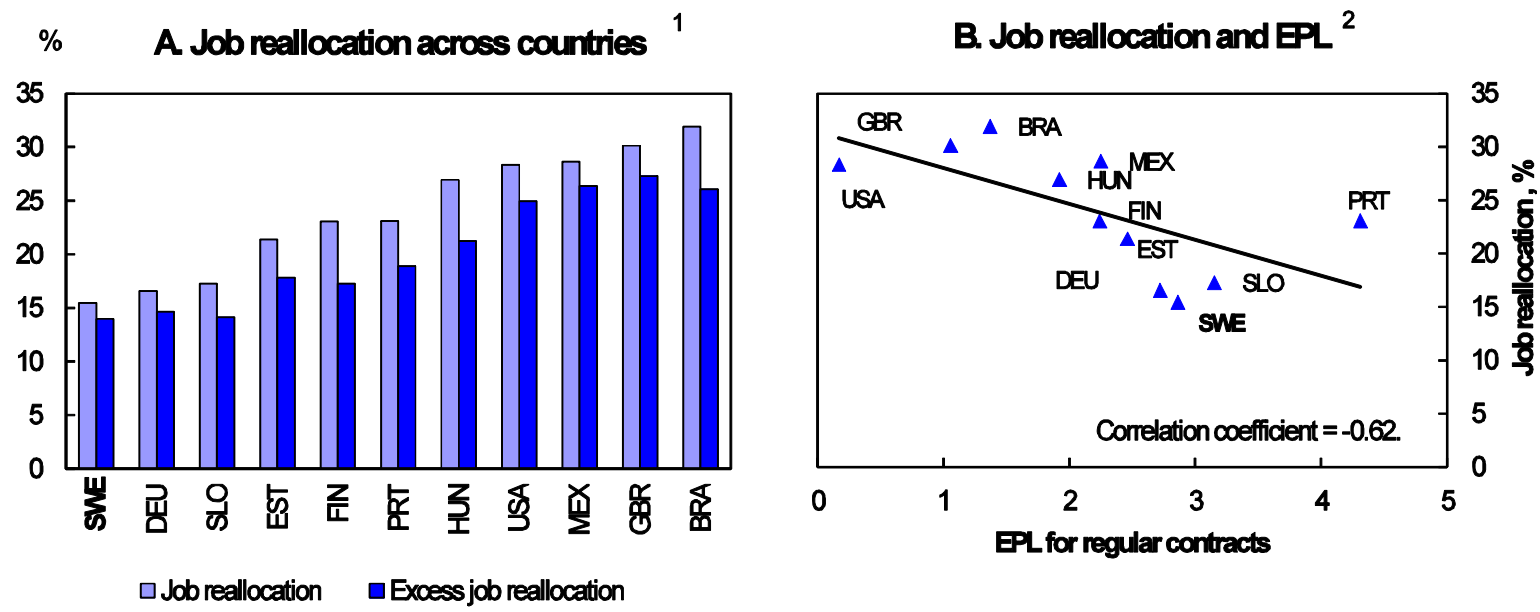

1. Job reallocation is the sum of job creation and job destruction between $t-1$ and $t$, excess job reallocation is job reallocation minus absolute net employment. The displayed rates are estimated averages which account for differences in industry composition across countries. Germany: 1997-98; Finland: 1997; Hungary: 1998-2000; Portugal: 1997; Mexico: 2000; Sweden: 1997-2003; United Kingdom: 1997-98; United States: 2001-04.

2. Job reallocation in 1997-2004 plotted against the average of EPL for regular contracts in 1997-2004. Correlation coefficient is -0.62 .

Source: OECD (2009a); OECD, Employment Protection Database.

While workers on regular contracts in Sweden have no legal entitlement to severance payments, a number of factors make EPL for regular contracts strict (Table 2):

- Procedures are heavy. If a worker is dismissed on personal grounds, or because of redundancy, the worker's trade union must be notified and has the right to launch relocation

12. Von Bulow and Thoursie (2010) study the specific effect of the "last-in-first-out" rule in Sweden. Using the exemption of small firms from this rule they do not find any large effect on hiring and firing rates. They suggest that this is because employers can circumvent the rule through negotiations with unions. 
negotiations. These can last up to six months and the notice cannot be served before the negotiations are concluded.

- The formal definition of a fair dismissal is strict and compensation for unfair dismissals is generous. In case of redundancy, dismissals are deemed fair only if the selection of workers is done in accordance with the "first-in-last-out" principle. If a worker is dismissed because of individual work capacity, the dismissal is deemed fair only if the employer has previously attempted to mitigate the problem by making adjustments to the workplace, or to rehabilitate or transfer the employee to other suitable work. While these rules can be circumvented through negotiations with the labour unions and firms with up to 10 employees face less restrictive rules (Bulow and Thorsie, 2010), the time used on these negotiations still implies higher dismissal costs. The high level of compensation for an unfair dismissal supplies the unions with leverage to achieve generous severance payments, which could explain why the share of dismissal cases tried in court is among the lowest in the OECD (Venn, 2009). Dismissal procedures and payments are agreed between employers and unions on a case-by-case basis, which gives rise to uncertainty about the dismissal costs for employers and inequality of treatment between workers.

- Notice periods are long compared to other OECD countries (Figure 13).

Reforms of EPL in Sweden ought to ease the protection on regular contracts. Some dismissal costs are appropriate, to ensure that employers internalise at least part of the social cost of labour turnover and to protect workers from arbitrary actions. EPL in other OECD countries could provide inspiration for reforming the Swedish model, although models in other countries would need to be adapted to Swedish circumstances (Box 3). In particular, the procedures could be eased by abolishing the right of the unions to launch negotiations during the pre-notice period while the strict definition of a fair dismissal needs to be relaxed, as previously recommended (OECD, 2007). Moreover, to ensure that the mobility of workers with long tenure is not impeded, the maximum notice period could be reduced. In addition, to avoid a long period with low-productivity work after a dismissal, legislation could be considered that would facilitate severance payments in lieu of the notice period. This, however, would need to be complemented with adjustments in the timing of unemployment benefits in order not to affect public finances adversely. 
Table 2. Components of the EPL indicator for Sweden

As of 2008

\begin{tabular}{|c|c|c|c|c|}
\hline \multirow[b]{2}{*}{ Regulation of... } & & \multicolumn{2}{|c|}{$\begin{array}{l}\text { Score on a scale from } 0 \text { (least } \\
\text { restrictive) to } 6 \text { (most } \\
\text { restrictive) }\end{array}$} & \multirow{2}{*}{$\begin{array}{l}\text { Sweden's rank } \\
\text { among OECD } \\
\text { countries } \\
\text { (1=most strict) }\end{array}$} \\
\hline & & $\begin{array}{l}\text { OECD } \\
\text { average }\end{array}$ & Sweden & \\
\hline \multirow{13}{*}{$\begin{array}{l}\text { Regular } \\
\text { contracts }\end{array}$} & Notification procedures & 3.0 & 4 & 3 \\
\hline & Delay involved before notice can start & 1.2 & 2 & 5 \\
\hline & $\begin{array}{l}\text { Length of notice period at } 9 \text { months of } \\
\text { tenure }\end{array}$ & 2.9 & 3 & 8 \\
\hline & $\begin{array}{l}\text { Length of notice period at } 4 \text { years of } \\
\text { tenure }\end{array}$ & 2.7 & 5 & 1 \\
\hline & $\begin{array}{l}\text { Length of notice period at } 20 \text { years of } \\
\text { tenure }\end{array}$ & 1.7 & 3 & 4 \\
\hline & Severance pay at 9 months of tenure & 0.7 & 0 & 8 \\
\hline & Severance pay at 4 years of tenure & 1.7 & 0 & 18 \\
\hline & Severance pay at 20 years of tenure & 1.6 & 0 & 22 \\
\hline & Definition of justified or unfair dismissal & 1.7 & 4 & 4 \\
\hline & Length of trial period & 4.1 & 4 & 10 \\
\hline & Compensation following unfair dismissal & 2.1 & 6 & 1 \\
\hline & $\begin{array}{l}\text { Possibility of reinstatement following } \\
\text { unfair dismissal }\end{array}$ & 2.6 & 2 & 15 \\
\hline & $\begin{array}{l}\text { Maximum time to make a claim of unfair } \\
\text { dismissal }\end{array}$ & 2.4 & 2 & 10 \\
\hline \multirow{3}{*}{$\begin{array}{l}\text { Fixed-term } \\
\text { contracts }\end{array}$} & Valid cases for use of fixed-term contracts & 1.5 & 0 & 19 \\
\hline & $\begin{array}{l}\text { Maximum number of successive fixed- } \\
\text { term contracts }\end{array}$ & 2.2 & 0 & 21 \\
\hline & $\begin{array}{l}\text { Maximum cumulated duration of } \\
\text { successive fixed-term contracts }\end{array}$ & 1.3 & 3 & 2 \\
\hline \multirow{5}{*}{$\begin{array}{l}\text { Temporary } \\
\text { work agencies }\end{array}$} & $\begin{array}{l}\text { Types of work for which temporary work } \\
\text { agency employment is legal }\end{array}$ & 1.4 & 0 & 18 \\
\hline & $\begin{array}{l}\text { Restrictions on number of renewals of } \\
\text { temporary work agency contracts }\end{array}$ & 2.8 & 2 & 15 \\
\hline & $\begin{array}{l}\text { Maximum cumulated duration of } \\
\text { successive temporary work agency } \\
\text { contracts }\end{array}$ & 1.9 & 2 & 11 \\
\hline & $\begin{array}{l}\text { Authorisation and reporting requirements } \\
\text { for temporary work agencies }\end{array}$ & 3.3 & 0 & 23 \\
\hline & $\begin{array}{l}\text { Regulations requiring equal treatment of } \\
\text { regular and agency workers }\end{array}$ & 4.0 & 0 & 24 \\
\hline \multirow{4}{*}{$\begin{array}{l}\text { Collective } \\
\text { dismissals }\end{array}$} & Definition of collective dismissal & 4.2 & 6 & 1 \\
\hline & $\begin{array}{l}\text { Additional notification requirements for } \\
\text { collective dismissals }\end{array}$ & 3.5 & 3 & 13 \\
\hline & $\begin{array}{l}\text { Additional delays involved before notice } \\
\text { can start for collective dismissals }\end{array}$ & 1.8 & 6 & 1 \\
\hline & $\begin{array}{l}\text { Other special costs to employers of } \\
\text { collective dismissals }\end{array}$ & 1.7 & 0 & 17 \\
\hline
\end{tabular}

Source: OECD, Employment Protection Database. 


\section{Box 3: Employment protection legislation in selected other OECD countries}

In Denmark, unemployment benefits are also generous but the level of EPL is relatively low. Moreover, the level of activation for the unemployed is high partly in order to induce workers to actively search for jobs. This is the so-called flexicurity model (Andersen and Svarer, 2005).

Since 2002, Austria has had a system of individual saving accounts (OECD, 2006a). Each employee has an account (administered by a fund that invests in private capital markets) funded by fixed employer contributions. In the case of a dismissal the employee can choose to receive severance payments from this account. If the employee decides not to, the funds are carried over to the next job. In fact, the account follows the employee through the entire working life. Nothing can be paid out if the employee voluntary terminates a job contract, but the remains are paid out upon retirement. Hence, the scheme in effect is a form of retirement saving. The upside of such a scheme is that it reduces the uncertainty faced by employers during dismissals. Moreover, it decreases employees' costs of job mobility as they do not loose entitlement to severance payments when they change jobs. As such a scheme would add to labour costs its introduction in Sweden would require to reform EPL by removing other forms of direct and indirect costs.

The Netherlands has a dual dismissal system (OECD, 2006a; OECD, 2006b). Employers can dismiss workers without severance payments if prior permission is given by a designated public authority (the Centre for Work and Income, CWI). This process is slow and entails uncertainty, as the CWI can deny the request and workers dismissed under this procedure may subsequently be awarded compensation or be reinstated by the courts. Alternatively, employers can terminate contracts via sub-district courts. These courts check the validity of the dismissal and usually impose a severance payment if the contract is dissolved. In practice, this procedure is more expensive but quicker and more predictable than the former. This may explain why the route through courts has been increasingly taken, particularly by large companies. The upside of this system is that it decreases uncertainty and makes the employers internalise at least some of the social costs of dismissals. However, the procedures for dismissals remain fairly heavy.

In the United States the level of EPL is the lowest in the OECD, while a system of experience-rated contributions to the unemployment insurance (UI) is in place (Fath and Fuest, 2005). In this system the UI is partly financed by employers through firm-specific contributions. These contributions vary positively with the share of dismissed workers claiming UI benefits in the previous few years. Experience-rated benefits imply that employers internalise parts of the social costs associated with dismissals, and in contrast to a system of uniform contributions do not implicitly subsidise sectors with high labour turnover. However, the introduction of such a system in Sweden would require a complete reform of the UI system. Furthermore, a downside of the system is that it leads to rising costs for employers following recessions, in turn, implying a risk of more bankruptcies during protracted downturns.

Recently, some academics have argued for bridging the gap between temporary and regular contracts by smoothing the cost of dismissal over tenure. This could be done by introducing a single contract in which statutory severance payments gradually increase up a national ceiling (Bentolila et al., 2008). In particular the severance payments could increase during each of the first quarters or years of a contract. Such a system would make firms internalise part of the social costs of a dismissal, decrease the uncertainty they face and promote the use of regular contracts with positive implications for on on-the-job training. However, this system would also give rise to counter-cyclical costs for employers. 
Figure 13. Notice periods in OECD countries

After 9 months, 4 years and 20 years in the job

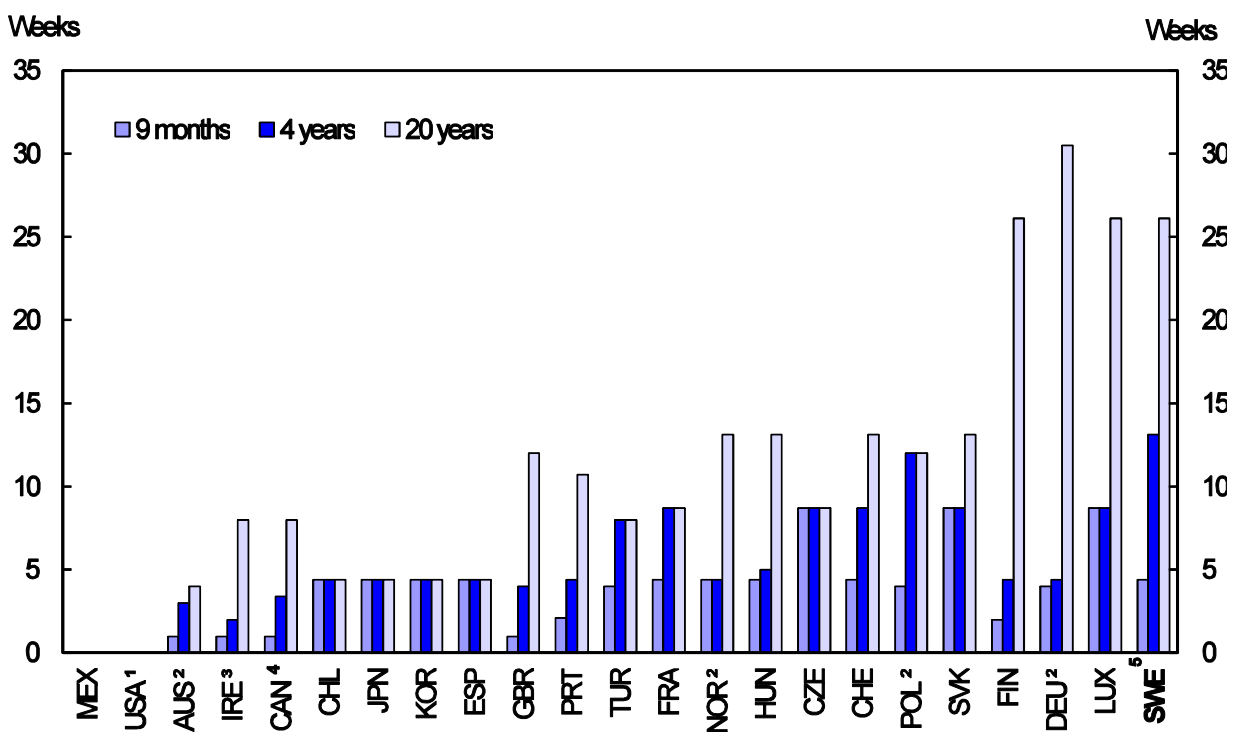

1. No legal regulation.

2. Special rules apply for workers above age 45 and 50 in Australia and Norway, respectively. In Germany special rules apply for workers below age 25. In Poland special rules apply for school leavers in first job and workers on trial periods.

3. Only workers covered by the Minimum Notice \& Terms of Employment Act excluding inter alia, defence forces, police and certain merchant shipping employment agreements.

4. Average for Quebec, Ontario, Alberta and British Columbia.

5. Deviations are possible by collective agreements.

Source: OECD (2010f).

If a broad-based reform of EPL does not prove feasible, a second-best solution would be to help the transition into regular employment by prolonging the trial period for regular contracts, as discussed in a previous OECD Economic Survey (OECD, 2007). However, this would not fully address the issues raised above.

\section{Strengthen job-search incentives further}

The introduction, and subsequent expansion, of the in-work tax credit and the reform of unemployment benefits have reduced unemployment and inactivity traps in Sweden substantially (OECD, 2007). However, social transfers, such as housing benefits and social assistance, continue to hamper job-search incentives for some non-employed persons (Figure 14). 
Figure 14. Work incentives for low-income persons, $2010^{1}$

Combining employee contributions, income taxes and benefit withdrawal

A Unemployment trap ${ }^{2}$
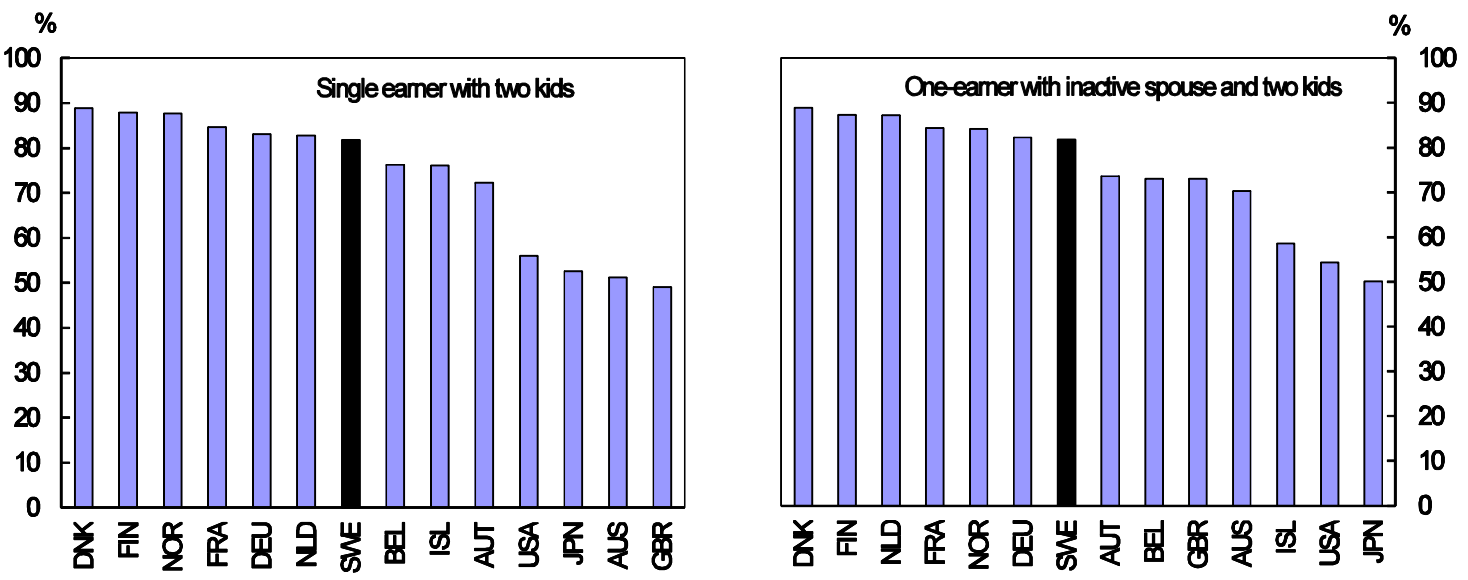

\section{B. Inactivity trap ${ }^{3}$}

$\%$

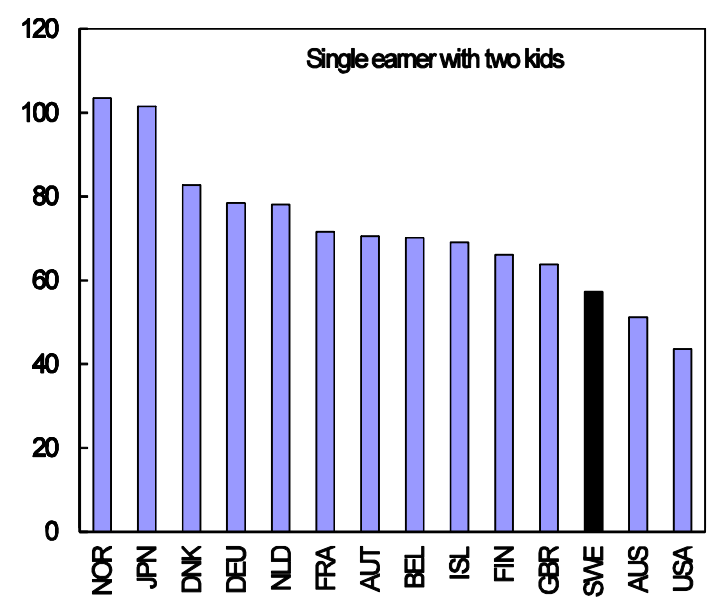

$\%$

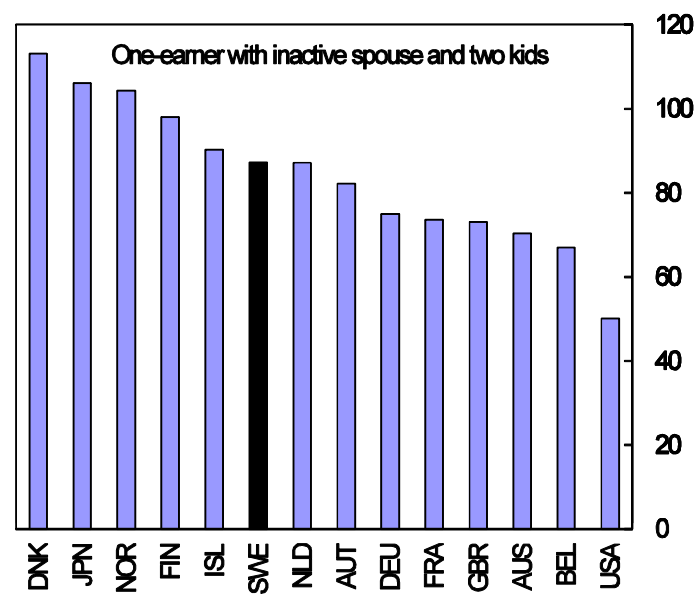

1. The figures are from 2010 for Sweden, while they are from 2008 for the rest of the countries.

2. Average Effective Tax Rate (AETR) on moving from unemployment benefits to full-time work earning $67 \%$ of average full-time earnings within 60 weeks of unemployment for a person having earned $67 \%$ before unemployment.

3. AETR on moving from inactivity to full-time work earning $67 \%$ of average full-time earnings.

Source: OECD, Tax Benefit model; Swedish Government (2007); Swedish Government (2009a).

Housing and family benefits could be redesigned to improve incentives to participate in the labour market, while preserving social protection for those who need it. Today, housing benefits, which the Budget Bill for 2011 stipulates will increase, are available for households with children and having low income. In addition they are available for individuals below age 29 with low income. In practice, this implies that some $60 \%$ of the recipients are either single parents or students. ${ }^{13}$ As

13. In $2009,50 \%$ of all recipients were single households with children. $21 \%$ of all recipients were households below age 29 with no children. Of the latter group 33\% are students. 
housing benefits are income-tested, they add to the average and marginal effective tax rate from $35 \%$ to $87 \%$ of full-time average earnings. This detrimental effect on work incentives could be mitigated by removing these benefits while increasing the (non-income tested) family benefits for groups at risk of poverty. Such a reform would be in line with the recommendations made by the Family Commission (SOU, 2001) and in a previous OECD Economic Survey (OECD, 2007). It would reduce the effective tax rates for single parents and could, in turn, increase labour supply. The income effect for some single parents already employed who would lose housing benefits while not benefiting from an increase in family benefits could lead them to reduce their hours worked. However, a comparable reform simulated on a sample of single mothers in Sweden suggests that both employment and total working hours supplied by this group are likely to increase (Flood et al., 2007). ${ }^{14}$

The fact that many unemployed rely on social assistance also undermines job-search incentives. In 2008, 4.5\% of the Swedish population received social assistance (Dahlberg et al., 2009). This share has likely increased since, owing to the rise in unemployment and a decline in the share of unemployed eligible for income-related unemployment benefits and unemployment assistance. ${ }^{15}$ As social assistance is withdrawn one-for-one against earned income, the unemployed on social assistance face a marginal effective tax of $100 \%$ when moving into employment at up to $40 \%$ of average earnings (Figure 15). This is very penalising compared with other OECD countries, and blunts the incentive to take on part-time employment. It could help to explain the relatively low incidence of this type of employment in Sweden (OECD, 2010d).

\section{Figure 15. Marginal effective tax rate for a worker not eligible for unemployment benefits ${ }^{1}$}

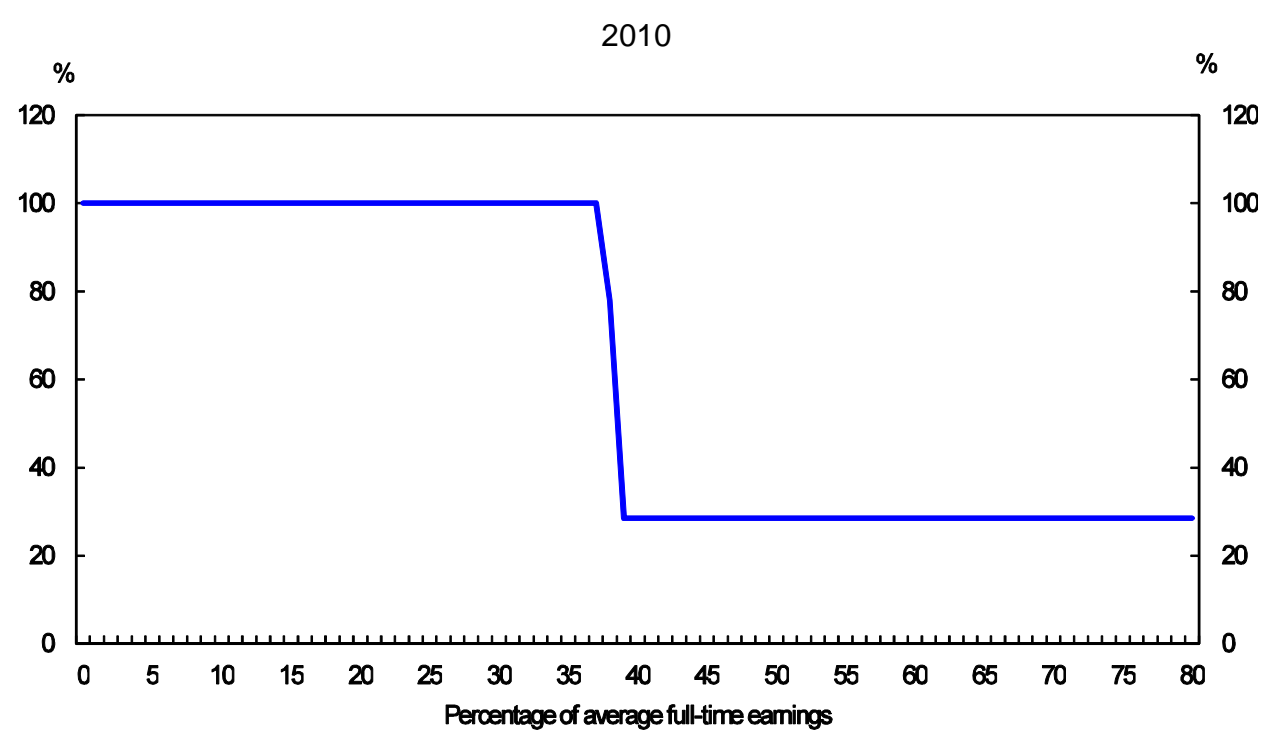

1. The marginal effective rate is computed using the parameters from the tax system in 2010 on the 2008 tax benefit model.

Source: OECD, Tax Benefit model; Swedish Government (2007); Swedish Government (2009a).

14. This reform also combined a cut in income tested benefits with a lump-sum increase in income. Specifically, the reform increased the basic tax deduction, reduced social assistance benefits and introduced maximum fees on childcare.

15. The share of unemployed receiving income-dependent unemployment benefits has decreased from around $60 \%$ in 2007 to $50 \%$ in 2009. The share of unemployed receiving only unemployment assistance has decreased from $10 \%$ in 2005 to $5 \%$ in 2009. 
The dependence of the unemployed on social assistance has also created two parallel ALMP systems in Sweden. Social assistance is administered by local governments, and they have developed ALMP schemes in an attempt to curb their expenditures. The content of these schemes, and the enforcement of the requirement of recipients to participate, varies significantly across local governments. In general, little is known about the effect of the programmes. Consequently a dual ALMP has emerged with measures run by both the PES and local governments (Dahlberg et al., 2009).

Extending the coverage of unemployment benefits could alleviate these problems by reducing the share of unemployed depending on social assistance. Under the current rules all unemployed are eligible for unemployment assistance if they fulfil the basic requirements and a work condition. ${ }^{16}$ However, only members of unemployment insurance agencies (UIAs) are eligible for incomedependent unemployment benefits. There are 32 UIAs, most of them being run by labour unions. Unemployment benefits are mainly financed by the government through grants $(60 \%$ of the cost in 2009 ) and also through fees from members (40\% of the cost). In 2007, fees were made differentiable across agencies so as to let labour market insiders bear a financial burden if wage growth caused unemployment to rise (OECD, 2007). In 2006, the government declared its intention to make unemployment insurance contributions mandatory, but subsequent reforms have lacked clear direction. In 2007, access to unemployment assistance for graduates was tightened, and the fees paid by the UIAs to the government were increased. As a consequence the UIAs increased their premiums, which contributed to a drop in the coverage from some $80 \%$ in 2006 to around $70 \%$ in 2009 (in per cent of the labour force). ${ }^{17}$ The government subsequently tried to increase coverage by decreasing fees in 2009 , but this was offset by the higher level of unemployment, which caused the UIAs to increase premiums again. In 2010, the government launched an inquiry on the sickness and unemployment insurance systems.

While making the unemployment insurance contributions mandatory would be useful, ensuring local coordination between municipalities and the PES will remain a challenge (OECD, 2007). In this regard, the experience from other OECD countries in setting up "one-stop-shops" for the unemployed could be emulated (Tergeist and Grubb, 2006). In the United Kingdom, the employment service and income support were merged into Jobcentre Plus, an one-stop-shop for both employment services and income support for inactive and unemployed persons, with a positive impact on job-entry outcomes (Karagiannaki, 2007; Corkett et al., 2005).

\section{Tighten the enforcement of sanctions}

Adverse effects on job search from income support can be offset at least to some extent by strict enforcement of availability requirements. This can encourage job search, help fill vacancies and bring down structural unemployment (Hasselpflug, 2005). However, the current administration of unemployment benefits creates problems in the sanctioning of reported violations of availability requirements. The PES monitors whether the unemployed fulfil the requirement for receiving benefits, whereas the UIAs pay out the benefits. Experience in OECD countries shows that competing UIAs that are not under strict government control can find ways to be more generous to their members than

16. The basic requirements stipulate the unemployed must be able and willing to take a job. The work condition implies that the unemployed should have either: worked at least 6 out of the past 12 months, with a minimum of 80 hours per month, or worked for at least 480 hours during a consecutive period of 6 months with at least 50 hours of work per month.

17. The number of members of UIAs fell from 3.79 million in December 2006 to 3.36 million in November 2009. 
the legislation allows (Duell et al., 2009). In Sweden, only 60\% of the reports on violations sent to the UIAs lead to sanctions: $6 \%$ of the reports were never treated by the UIAs and $25 \%$ were not valid as they concerned individuals not receiving benefits; of the treated and valid reports $85 \%$ lead to a sanction (IAF, 2010).

A related priority is to ensure that violations of the availability requirements are duly reported by the PES. The National Audit Office has documented that the PES reports only some of the actual violations (Riksrevisionen, 2005). More recent evidence points to regional differences in reporting procedures (Okeke, 2008). The PES was reorganised in 2008 to mitigate these problems by separating the responsibility for support from that of monitoring. However, so far the effects of this reform appear uncertain as the number of reports in 2009/10, adjusted for the level of unemployment and vacancies in the economy, reached a historical minimum (IAF, 2010). To ensure that reported violations do lead to a sanction by UIAs and to increase the incentives for the PES to report violations and improve the quality of its services, the administration of unemployment benefits and the job-placement service should be better coordinated or merged. Merging the two institutions would require replacing the current system of numerous union-organised unemployment insurance agencies by a simpler national system.

More gradual, as opposed to tougher, sanctions could help. Experience from other OECD countries shows that a more systematic application of sanctions is likely to be more efficient than stricter sanctions. Indeed, overly strict sanctions may tend to weaken enforcement, insofar as case workers consider them too harsh to be applied (OECD, 2006a). Analysis from Switzerland shows that even mild sanctions, such as warnings, can have a significant positive effect on the exit rate out of unemployment (Lalive et al., 2005). Other countries (e.g. France) have combined a greater use of sanctions with some reduction in the size of the sanction imposed for the first violation. Today, the initial sanction for non-compliance of the unemployed in Sweden is a cut in benefits of $25 \%$ during 40 days. A second occurrence leads to a cut of $50 \%$ for another 40 days. As a final sanction, the unemployed person looses the right to benefits altogether. The government could consider combining a tightening of reporting procedures with even more gradual sanctions, e.g. by increasing the use of warnings before benefits are cut. Such warnings, however, need to be backed by credible threats about subsequent cuts in benefits in case of non-compliance.

To promote efficient reporting and follow-up, as well as best practices in general, the government could also consider implementing performance indicators for the PES like in some other OECD countries. Switzerland for example has since 2000 published ratings at the regional level of the performance of local PES offices adjusted for the labour market situation in the area (Duell et al., 2010). The mere publication of such indicators could act as an incentive to improve performance and ultimately the remuneration of managers in the PES could be linked to such indicators.

Tightening the regional search requirements could also improve the matching process and bring down structural unemployment. Before the onset of the recession unemployment rates were higher in Sweden's rural regions than in the urban areas. The recession widened this gap as the rural regions were hit harder owing to their reliance on manufacturing (OECD, 2010a). In 2007, the government abolished the rule that allowed unemployed to limit their job-search geographically in the first 100 days of unemployment, but the enforcement of the new rules is weak (Riksrevisionen, 2009a). Tightening the administration of the geographical search requirements would help, but obstacles such as strict rent regulation are likely to continue to impede the regional mobility of labour (OECD, 2010e). Further facilitation of mobility would therefore require reforms of the Swedish housing market, as discussed in depth in a previous OECD Economic Survey (OECD, 2007). 


\section{Continuing with reform of the disability benefit schemes}

An important challenge is to ensure that the recent expansion of the labour force with former recipients of incapacity benefits (Figure 16) ultimately leads to a higher level of employment. The 1997 Swedish disability reform illustrates that abolishing incapacity schemes does not automatically boost employment, as there is a risk that other labour market programmes will have to absorb the workers (Karlström et al., 2008). ${ }^{18}$ In this regard, the financial incentives given to recipients of disability benefits to return to the labour market are welcome. However, if this measure, along with the improved gate-keeping mechanisms (Table 3), proves to lead to an insufficient reduction in the stock of recipients, further decreasing the replacement ratio, which is still above the OECD average (OECD, 2009b), could be considered. Another priority is to ensure that the improved gate-keeping procedures for incapacity benefits are implemented. In addition, the government could consider improving gate-keeping further, e.g. by delegating the medical evaluation for longer sickness spells to special insurance teams as discussed in a previous OECD Economic Survey (OECD, 2005).

Figure 16. Sickness leave and disability pension

Percentage of working-age population
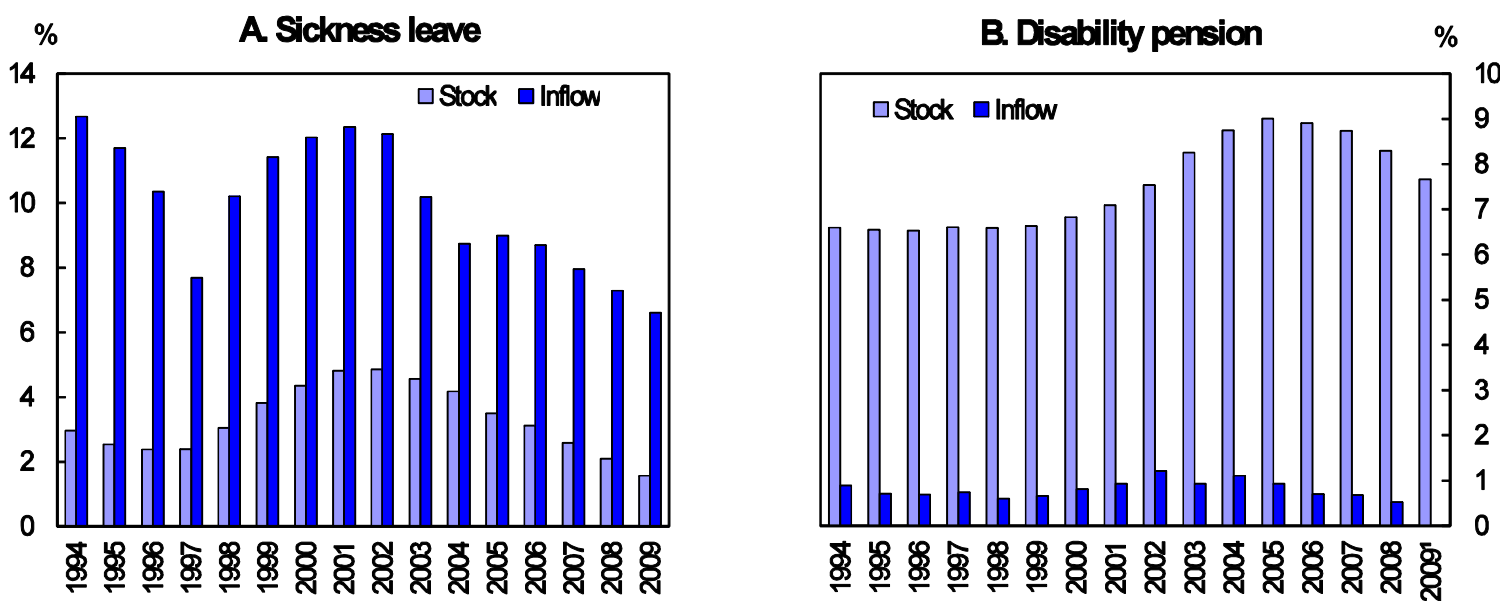

1. Inflows are not available for 2009.

Source: Swedish Fiscal Policy Council (2010); Swedish Social Insurance Agency; OECD Analytical Database.

18. Karlström et al. (2008) did not find that the disability reform in 1997, which abolished special eligibility rules for the age group 60-64, increased employment for this age group. Instead other labour market programmes absorbed the workers. 
ECO/WKP(2011)11

Table 3. Sickness and disability reforms since 2006

Situation in 2006

Unlimited sickness benefit duration

The employer finances the first 14 days of sickness absence and $15 \%$ afterwards, and is required to prepare rehabilitation investigation

Disability benefit can be either temporary or permanent

Disability beneficiaries are entitled to their benefit if they attempt work for up to two years; they will be reassessed if at work for longer

Various subsidies available for companies employing a person with disabilities.
Situation in 2010

Sickness benefit for a maximum of one year, but only after 90 days if the individual have no work capacity to perform any job at his or her workplace, and only after 180 days there is no work capacity to perform any job in the labour market. Prolonged sickness benefit can be granted for a maximum of 550 days.

The employer finances only the first 14 days, and may be asked to provide the Social Insurance Agency (SIA) with information needed for rehabilitation planning. The SIA can demand that a sick worker requests from their employer a certificate showing what has been done to accommodate the employee.

Disability benefit is only granted for permanent reductions in work capacity. However, the recipient's work capacity will be reassessed every third year.

Disability beneficiaries are guaranteed not to be reassessed if they attempt paid work and are allowed to earn a substantial amount of income and still keep their benefit

A new "Special new-start job" subsidy amounting to twice the employers' contributions when hiring long-term unemployed and individuals previously on sickness, rehabilitation or disability benefits

1. Exemptions can be made if the individual due to health reasons is unable to participate in activities within the Public Employment Service.

Source: OECD (2009b); Regeringskansliet (2009e); Försäkringskassan (2010).

\section{Enhance wage flexibility}

The high minimum cost of labour in Sweden could prove to be a significant barrier to the integration of the former recipients of incapacity benefits in the labour market (Figure 16). The high level is mainly caused by the minimum wages set in collective agreements, but employer contributions also add to the cost of labour (31.4\% for workers aged $26-65$ and $15.5 \%$ for younger workers). As the high minimum cost of labour increases the productivity threshold from which it is profitable to hire workers, the employment of low-productivity groups could be adversely affected. Empirical evidence suggests a negative effect of minimum wages on employment of low-productivity workers in the hotel and restaurant sector, where the minimum wage is among the highest in the economy (Skedinger, 2006). A recent survey also indicates that in 2008 around $15 \%$ of all unemployed and around $26 \%$ of workers with a pre-history of incapacity benefits had a "hypothetical" 19 wage below the relevant minimum wage, suggesting that the minimum wage can be an obstacle to their entry into the labour market (Konjunkturinstitutet, 2010).

The high level of minimum wages is influenced by the organisation of wage negotiations. No minimum wage is legislated in Sweden, but collective agreements specify minimum wages for employees in different sectors (Skedinger, 2007). These agreements also differentiate minimum wages across individual characteristics such as age, work experience and location. All workers employed in a

19. The "hypothetical" wage is based on past wages adjusted to account for the negative impact of unemployment on wages. 
company that is a member of the signatory employer organisation are covered by a collective agreement, whether workers are unionised or not. This implies that $80 \%$ of workers are covered by minimum wages. In addition, the employees of non-member companies can achieve coverage if the company signs an agreement with the relevant labour union, implying that another $10 \%$ of workers are covered through this mechanism (Medlingsinstitutet, 2008). Non-member companies have strong incentives to sign such an agreement as unions are entitled to take action against non-signatory firms even if the workplace has no union members.

According to theoretical and empirical studies, negotiations at the sector level leads to higher wage outcomes than negotiations at the local level (Calmfors and Drifill, 1988; OECD, 2006a). In Sweden, wage negotiations have become more decentralised since the 1990s but minimum wages continue to be set at a sectoral level (Skedinger, 2007). Several options could be considered to ensure that minimum wages do not price out low-productivity workers. Under the current system, transparent opt-out clauses could be introduced allowing for local wage agreements at levels below the minima. Alternatively, an independent commission could be set up, in the vein of the UK Low Pay Commission, which would play a role and advise on the impact of minimum wages on employment. In the latter case, the size of the fees paid by UIAs to the government could be made conditional on whether the negotiated minimum wages are in line with the independent commission's recommendations. Finally, making unemployment insurance contributions mandatory could also help align minimum wages better with productivity. This is because labour unions would have to take into account the employment prospects of a larger range of workers. Furthermore, breaking the link between the affiliation to a union and the entitlement to unemployment benefits is likely to weaken the bargaining power of labour unions.

\section{Box 4. Measuring the minimum cost of labour in Sweden}

No minimum wage is legislated in Sweden, but collective agreements specify minimum wages for employees in different sectors (Skedinger, 2007). These agreements also differentiate minimum wages across individual characteristics such as age, work experience and location. All workers employed in a company that is a member of the signatory employer organisation are covered by a collective agreement. Furthermore, the employees of non-member companies can achieve coverage if the company signs an agreement with the relevant labour union. In practice, this implies that $90 \%$ of all workers in Sweden are covered by collective agreements (OECD, 2004).

Using seven collective agreements ${ }^{a}$ covering manual workers in both the manufacturing and service industries, Skedinger (2007) has constructed a range of minimum wages for a prototype Swedish worker. ${ }^{\mathrm{b}}$ The lowest of these wages can be used as a proxy for the "minimum wage" in Sweden. Adding social contributions to this minimum wage yields a minimum labour cost of $63 \%$ of the median wage in 2008 and $55 \%$ of the median wage when considering the lower social security contribution for workers below age 26 . This is much higher than in most OECD countries with statutory minimum wages (Figure 17), but comparable to the level in Finland where minimum wages also are stipulated in collective agreements (OECD, 2006c). 
Figure 17: Minimum cost of labour

2009

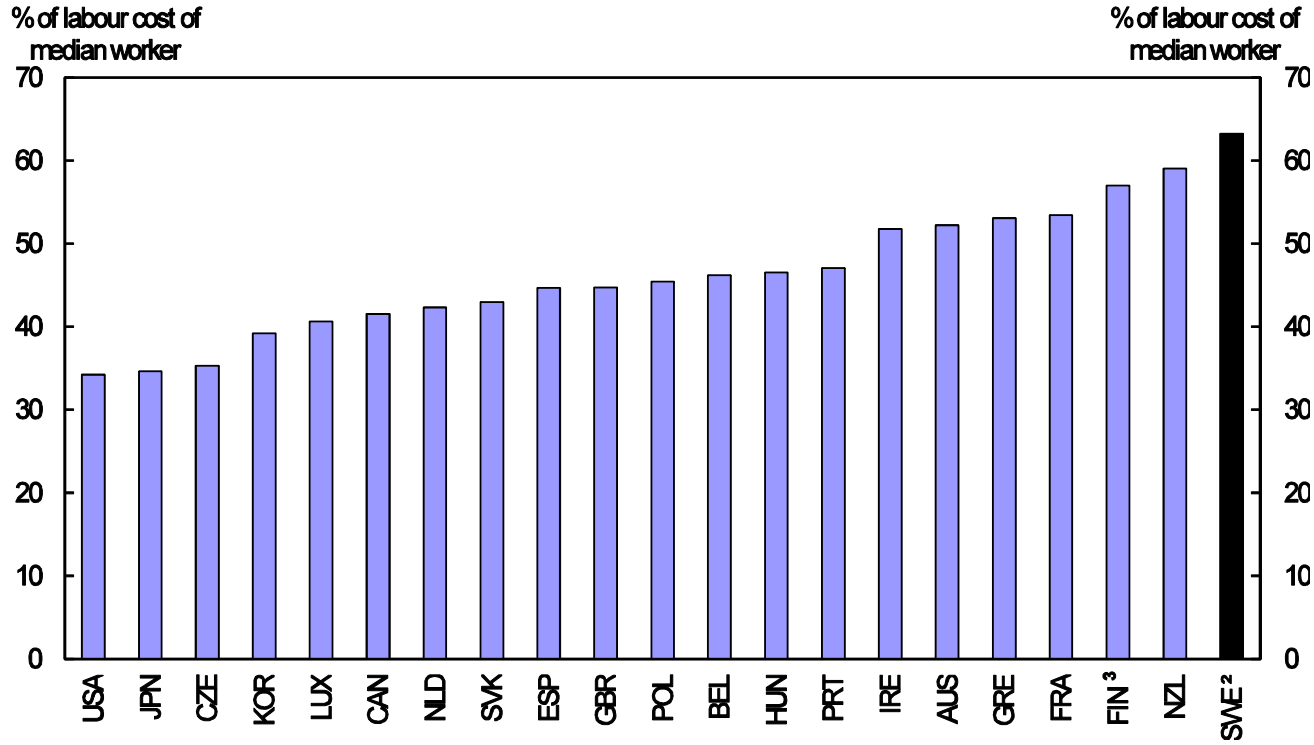

1. The cost of labour is the sum of the wage level and the corresponding social security contribution paid by employers.

2. The minimum wage in Sweden is computed as the lowest negotiated minimum wage across sectors plus the social security contributions paid for employees above the age of 26 . The median wage used is the median wage for workers in the private sector.

3. The minimum labour cost for Finland is from 2004 and calculated on data provided by national authorities.

Source: OECD, Going for Growth database: calculations on data from Skedinger (2007); Statistics Sweden; OECD (2006c).

a. $\quad$ The used agreements are: "Engineering Agreement" (Teknikavtalet Metall, formerly Verkstadsavtalet), the "Construction Agreement" (Byggnadsavtalet), the "Slaughter-house Agreement" (Slakteri- och charkuteriavtalet), the "Bakery Agreement" (Bageriavtalet), the "Retail Trade Agreement" (Detaljhandelsavtalet), the "Hotels and Restaurants Agreement" (Hotell- och restaurangavtalet) and the "Local Government Agreement" (Kommunalavtalet).

b. The prototype has the following characteristics: at least aged 20 , no work experience and employed in an unskilled occupation in a non-metropolitan area. 


\section{Box 5. Summary of labour market recommendations}

\section{Active labour market policy} search.

Progressively move the ALMP mix away from work experience placement schemes towards training and job

Improve the targeting of ALMP by increasing the use of profiling to identify individuals at risk of becoming long term unemployed and revisiting the eligibility criteria for the employment incentive scheme (Nystartsjobb).

\section{Education policy}

Consider moving gradually towards a system of tuition fees for tertiary education while extending the government loans available for students to finance tuition costs. Repayment of these loans could be made contingent on future income provided marginal income taxes are reduced.

Further develop information on and indicators of the performance of vocational education and make them publically available.

Assess the impact of using education programmes for unemployed workers' probability of moving into employment and on the quality of the education system.

\section{Hours worked and job-search incentives}

To lower marginal tax rates for workers with above-average earnings, reduce the state income tax and offset the fall in government revenues by, for instance, raising property taxes.

Continue to improve the job-search incentives of the unemployed by reducing the tax wedge and reforming social benefits. In particular a cut in housing benefits could be combined with a targeted increase in family benefits.

Extend the coverage of unemployment insurance by making unemployment insurance contributions mandatory.

Strengthen the implementation of sanctions when job-search requirements are not met while making sanctions more gradual. Strongly improve coordination between the job-placement service and the administration of unemployment benefits. Implement performance indicators for the PES.

\section{Employment protection legislation}

Reduce the protection of workers on regular contracts by easing procedures for individual and collective dismissals. Consider legislation to facilitate the use of severance payments in lieu of the notice period.

\section{Wage flexibility}

Promote the use of transparent opt-out clauses allowing for local wage agreements at levels below the minima or consider moving towards a system where an independent commission plays a role and advises on the impact of minimum wages on employment.

\section{Sickness and disability benefits}

Continue the reforms to improve the gate-keeping to sickness and disability benefits.

If the ongoing reforms of the sickness and disability benefit scheme fail to reduce substantially the number of recipients of these benefits, lower the replacement ratio further. 


\section{BIBLIOGRAPHY}

Andersen, T. and M. Svarer (2006), "Flexicurity - the Danish Labour Market Model", Ekonomisk Debatt, No. 1.

Andersen, T., B. Holmström, S. Honkapohja, S. Korkman, H. Söderströmand J. Vartiainen (2007), The Nordic Model, The Research Institute of the Finnish Economy, Helsinki.

Arai, M. and P. Thoursie (2005), "Incentives and Selection in Cyclical Absenteeism", Labour Economics, Vol. 12.

Arbetsförmedlingen (2009), "Prognoser för utbetalningar 2009 - 2012", http://www.arbetsformedlingen.se/Om-oss/Varverksamhet/Resultat/Rapporter/Aterrapportering/9-29-2009-Prognoser-for-utbetalningar-20092012.html.

Bassanini, A. and R. Duval (2006) "Employment Patterns in OECD Countries: Reassessing the Role of Policies and Institutions", OECD Economics Department Working Papers, No. 486.

Bassanini, A., J. Rasmussen and S. Scarpetta (1999), “The Economic Effects of EmploymentConditional Income Support Schemes for the Low-Paid - an Illustration From a CGE Model Applied to Four OECD Countries", OECD Economics Department Working Papers, No. 224.

von Below, D. and P. Thoursie (2010), "Last In, First Out? Estimating the Effect of Seniority Rules in Sweden ", Labour Economics, forthcoming.

Bennmarker, H., K. Carling and A. Forslund (2007), "Vem blir långtidsarbetslös", IFAU Rapport, No. 7.

Bentolila, S., J. Dolado and J. Jimeno (2008), "Two-Tier Employment Protection Reforms: The Spanish Experience”, CESifo DICE Report, No. 4.

Blöndal, S. and M Pearson (2010), "Unemployment and Other Non-Employment Benefits", Oxford Review of Economic Policy, Vol. 11, No. 1.

Booth, A., J. Dolado and J. Frank (2002), "Symposium on Temporary Work: Introduction", The Economic Journal, Vol. 112, No. 480.

Calmfors, L., J. Driffill, S. Honkapohja and F. Giavazzi (1988), "Bargaining Structure, Corporatism and Macroeconomic Performance", Economic Policy, Vol. 3, No. 6.

Calmfors, L., A. Forslund and M. Hemström (2001), "Does Active Labour Market Policy Work? Lessons From the Swedish Experiences", Swedish Economic Policy Review, Vol. 8.

Calmfors, L. (2008), “Kris i det svenska avtalssystemet?”, Ekonomisk Debatt, No. 1.

Corkett, J., S. Bennett, J. Stafford, M. Frogner and K. Shrapnell (2005), "Jobcentre Plus Evaluation: Summary of Evidence", Department for Work and Pensions Research Report, No. 252. 
Dahlberg, M., K. Edmark, J. Hansen and E. Mörk (2009), "Fattigdom i Folkhemmet”, IFAU Rapport, No. 4.

Duell, N., D. Grubb and S. Singh (2009), “Activation Policies in Finland”, OECD Social, Employment and Migration Working Papers, No. 98.

Duell, N., P. Tergeist, U. Bazant and S. Cimper (2010), "Activation Policies in Switzerland”, OECD Social Employment and Migration Working Papers, No. 112.

Erlandsen, E. and J. Lundsgaard (2007), "How Regulatory Reforms in Sweden Have Boosted Productivity”, OECD Economics Department Working Papers, No. 577.

Fath, J. and C. Fuest (2005), "Experience Rating of Unemployment Insurance in the US: A Model for Europe?", CESifo DICE Report, No.2.

Flood, L., R. Wahlberg and E. Pylkkänen, "From Welfare to Work: Evaluating a Tax and Benefit Reform Targeted at Single Mothers in Sweden", Labour, Vol. 21, No. 3.

Forslund, A. (2008), Den svenska jämviktsarbetslösheten: en översikt, Studier i Finanspolitik, No. 4, Finanspolitiska Rådet.

Fredriksson, P. (1997), “Economic Incentives and the Demand for Higher Education”, Scandinavian Journal of Economics, Vol. 99, No. 1.

Frölich, M., M. Lechner and H. Steiger (2004), "Statistically Assisted Programme Selection International Experiences and Potential Benefits for Switzerland", IFAU Working Paper, No. 1.

Furceri, D. and A. Mourougane (2009), "How Do Institutions Affect Structural Unemployment in Times of Crisis?", OECD Economics Department Working Papers, No. 730.

Furceri, D. and A. Zdzienicka (2010), "The Effect of Banking Crises on Human Capital”, mimeo.

Guichard, S. and E. Rusticelli (2010), "Assessing the Impact of the Financial Crisis on Structural Unemployment in OECD Countries", OECD Economics Department Working Papers, No. 767.

Hasselpflug, S. (2005), “Availability Criteria in 25 Countries", Danish Ministry of Finance Working Paper, No. 12.

Hägglund, P. and P. Thoursie (2010), "De senaste reformerna inom sjukförsäkringen: En diskussion om deras förväntade effekter”, Studier i Finanspolitik, No. 5, Finanspolitiska Rådet.

IAF (2010), "Underrättelser om ifrågasatt rätt till arbetslöshetsersättning och sanktioner i arbetslöshetsförsäkringen", http://www.iaf.se/Global/Tillsyn/Rapporter-pm/2010/20103Underr.pdf.

IF Metall (2009), "12 000 uppsägningar har undvikits", http://www.ifmetall.se/ifmetall/home/home.nsf/LUUnique/65DAAD11CBB057A1C125767B004 $65 B E$ 


\section{ECO/WKP(2011)11}

Karagiannaki, E. (2007), "Exploring the Effects of Integrated Benefit Systems and Active Labour Market Policies: Evidence from Jobcentre Plus in the UK", Journal of Social Policy, Vol. 36, No. 2.

Karlstrom, A., M. Palme and I. Svensson (2008), "The Employment Effect of Stricter Rules for Eligibility for DI: Evidence from a Natural Experience in Sweden", Journal of Public Economics, Vol. 92, No. 10-11.

Konjunkturinstitutet (2007), Lönebildningsrapporten 2007, Stockholm.

Konjunkturinstitutet (2010), Lönebildningsrapporten 2010, Stockholm.

Lalive, R., J. van Ours and J. Zweimüller (2005), "The Effect of Benefit Sanctions on the Duration of Unemployment", Journal of the European Economic Association, Vol. 3, No. 6.

Liebig, T. (2009), "Jobs For Immigrants: Labour Market Integration in Norway", OECD Social, Employment and Migration Working Papers, No. 94.

Lindbeck, A., M. Palme and M. Persson (2006), "Job Security and Work Absence: Evidence From a Natural Experiment", Research Institute of Industrial Economics Working Paper, No. 660.

Lundin, D. and L. Liljeberg (2008), “Arbetsförmedlingens arbete med nystartsjobben”, IFAU Rapport, No. 9.

Martinson, S. and K. Sibbmark (2010), "Vad gör de i jobb- och utvecklingsgarantin?”, IFAU Rapport, No. 15.

Medlingsinstitutet (2008), “Avtalsrörelsen och lönebildningen 2009”, Medlingsinstitutets Årsrapport, Stockholm.

OECD (2002), Employment Outlook, Paris.

OECD (2004), Employment Outlook, Paris.

OECD (2005), Employment Outlook, Paris.

OECD (2006a), Employment Outlook, Paris.

OECD (2006b), OECD Economic Surveys: Netherlands, Paris.

OECD (2006c), OECD Economic Surveys: Finland, Paris.

OECD (2007), OECD Economic Surveys: Sweden, Paris.

OECD (2008), OECD Economic Surveys: Sweden, Paris.

OECD (2009a), Employment Outlook: Tackling the Jobs Crisis, Paris.

OECD (2009b), "Sweden: Will the Recent Reforms Make it?", Sickness, Disability and Work: Breaking the Barriers, Paris. 
OECD (2009c), "Maintaining the Actication Stance During the Crisis", OECD Labour and Employment Ministrial Meeting Background Document, Paris.

OECD (2010a), OECD Territorial Reviews: Sweden, Paris.

OECD (2010b), Taxing Wages 2008-2009, Paris.

OECD (2010c), "Return to Work After the Crisis", OECD Economic Outlook, No. 87, Paris.

OECD (2010d), Employment Outlook, Paris.

OECD (2010e), “The Role of Structural Policies in Housing Markets”, ECO/WP/CPE/WP(2010)14, Paris.

OECD (2010f), "Detailed Description of Employment Protection in OECD and Selected Non-OECD Countries, 2008", http://www.oecd.org/dataoecd/24/39/42740165.pdf.

OECD (2011), OECD Economic Surveys: Sweden, Paris.

Okeke, S. (2008), "Regionala skillnader i kontrollfunktionen", Arbetsförmedlingen Working Paper Series, No. 6.

Riksbank (2010a), Monetary Policy Report, February, Stockholm.

Riksrevisionen (2005), “Arbetslöshetsförsäkringen - kontroll och effektivitet”, RiR, No. 3, Stockholm.

Riksrevisionen (2009a), “Omställningskraven i arbetslöshetsförsäkringen”, RiR, No. 13, Stockholm.

Riksrevisionen (2009b), “Jobbskatteavdraget”, RiR, No. 20, Stockholm.

Riksrevisionen (2009c), “Jobb- och utvecklingsgarantin - en garanti for jobb?”, RiR, No. 22, Stockholm.

Scarpetta, S., A. Sonnet and T. Manfredi (2010), "Rising Youth Unemployment During the Crisis", OECD Social, Employment and Migration Working Papers, No. 106.

Skedinger, P. (2006), "Minimum Wages and Employment in Swedish Hotels and Restaurants", Labour Economics, Vol. 13, No. 2.

Skedinger, P. (2007), "The Design and Effects of Collectively Agreed Minimum Wages: Evidence from Sweden", IFN Working Papers, No. 700.

Svarer, M. and M. Rosholm (2004), "Estimating the Threat Effect of Active Labour Market Programmes", IZA Discussion Paper, No. 1300.

SOU (2001), “Ur fattigdomsfällan”, Statens offentliga utredningar, No. 2001:24.

SOU (2010), "Lärling - en bro mellan skola och arbetsliv", Statens offentliga utredningar, No. 2010:19.

Swedish Fiscal Policy Council (2010), Report of the Swedish Fiscal Policy Council, Stockholm. 
ECO/WKP(2011)11

Swedish Government (2008a), "Budget Bill for 2009”, Proposition, No. 2008/09:1, Stockholm.

Swedish Government (2008b), “Sänkt skatt på förvärvsinkomster”, Promemoria, June, Stockholm.

Swedish Government (2009a), "Ett ytterligare förstärkt jobbskatteavdrag", Proposition, No. 2009/10:42, Stockholm.

Swedish Government (2009b), “Budget Bill for 2010”, Proposition, No. 2009/10:1, Stockholm.

Swedish Government (2009c), "Measures for Jobs and Adjustment", Proposition, No. 2008/09:97, Stockholm.

Swedish Government (2009d), “2009 Spring Fiscal Policy Bill”, Proposition, No. 2008/09:100, Stockholm.

Swedish Government (2010a), “2010 Spring Fiscal Policy Bill”, Proposition, No. 2009/10:100, Stockholm.

Swedish Government (2010b), "Budget Bill for 2011”, Proposition, No. 2009/10:1, Stockholm.

Tergeist, P. and D. Grubb (2006), "Activation Strategies and the Performance of Employment Services in Germany, the Netherlands and the United Kingdom", OECD Social, Employment and Migration Working Papers, No. 42.

Venn, D. (2009), "Legislation, Collective Bargaining and Enforcement: Updating the OECD Employment Protection Indicators", OECD Social, Employment and Migration Working Paper, No. 89.

Wallette, M. (2005), “Temporary Jobs and On-the-Job Training in Sweden - A Negative Nexus?", Lund University Department of Economics Working Paper, No. 13.

World Bank (2010), Doing Business 2010, Washington DC. 


\section{ANNEX 1. UNEMPLOYMENT BENEFITS AND ACTIVE LABOUR MARKET POLICY PROGRAMMES IN SWEDEN}

\section{Unemployment benefits}

Unemployed workers with insurance are provided unemployment benefits for a maximum duration of 60 weeks (90 weeks for unemployed with dependent children). The gross replacement rate is $80 \%$ for the first 40 weeks and $70 \%$ for the following 20 weeks. After 60 weeks of unemployment, the unemployed is referred to the Job and Development Guarantee, where she or he receives activity support with a gross replacement rate of $65 \%$. However, for many workers the replacement rate is de facto lower as both unemployment benefits and activity support are capped at 50\% of average earnings.

Unemployed workers without insurance are provided with unemployment assistance if they fulfil the work condition. Unemployment assistance has at flat rate of $24 \%$ of average earnings, and the maximum duration is 60 weeks (90 weeks for unemployed with dependent children). After 60 weeks of unemployment, they are referred to the Job and Development Guarantee, where development support is paid at a flat gross replacement rate of $16 \%$ of average earnings.

\section{Job and Development Guarantee and the Job Guarantee for the Youth}

The Job and Development Guarantee (Jobb- och utvecklingsgarantin) (JDG) provides the overall framework for the long-term unemployed, and aims at bringing them back into employment through individually designed activities. The unemployed are referred to the JDG after 60 weeks in unemployment. The first phase of the guarantee lasts 30 weeks and mainly involves job search and coaching activities. Phase two lasts 60 weeks and is meant to provide work experience to the harder-to-place participants. In phase three, the participants are supposed to be given permanent employment by private or public employers. The participants receive public benefits and the employer will pay neither wage nor social contributions or insurance. Participants' ability to work will be reviewed every second year. The third phase of the guarantee is open-ended, and participants are meant to stay in the guarantee until regular employment is found or they enrol in the education system. Participants are obliged to continue job-search activities with the assistance of the Public Employment Service.

The unemployed youth (16-24 years) are referred to the Job Guarantee for the Youth (Jobbgarantin för ungdomar) after 12 weeks of unemployment. Phase one lasts at least three months and consists of job search and coaching activities. In phase two, participants may be offered workplacement or short training measures. Participation cannot extend beyond 15 months or until the participant reaches the age of 25 . Thereafter, the person is referred to the JDG.

\section{ALMP programmes}

\section{Preparatory activities}

These include individually designed activities such as job search, rehabilitation, coaching or preparation for participation in labour market training. 


\section{Work experience placement ${ }^{1}$}

The above 25-year old unemployed and employed at risk of unemployment can be referred to work experience placement. The PES can refer the unemployed to placement at private, public or nonprofit organisations for at most six months. During the placement the participants can be summoned to mandatory meetings with the PES.

Lyft - a temporary scheme in place in 2010 only - targets the unemployed and the employed at risk of unemployment. The scheme offers activation within public or non-profit organisations. For participants who are not enrolled in the JDG the duration is up to three months, whereas the limit is up to six months for participants enrolled in the JDG. During placement the participant is obliged to use $25 \%$ of her or his time on job search.

Prova-på-plats targets the unemployed with limited work experience. The scheme offers work experience placement in private and public organisations. The maximum duration is three months.

Praktisk kompetensutveckling targets the unemployed and the employed at risk of unemployment, with previous work experience. The maximum duration is three months.

\section{Subsidised employment}

Särskilt anställningsstöd targets the unemployed who have been unemployed for at least two years and provides the employer with a subsidy of up to $85 \%$ of the wage cost. The maximum duration of the subsidy is four years. However, exemptions can be made.

Instegsjobb targets immigrants who gained a residence permit within the past three years. The subsidy is up to $80 \%$ of the wage costs and the maximum duration is 24 months.

$N y$ startsjobb targets the unemployed who have been unemployed, participating in other ALMPs (excluding subsidised employment) or receiving social assistance, sickness or disability benefits for more than a year. Workers aged 20 to 25 , and as a temporary measure in 2010-12 also workers aged 55 to 65 , qualify already after six months. While lower for youth, the subsidy amounts to twice the employer social security contributions. The maximum duration is one year for workers aged 20 to 25 (five years for workers who have received sickness or disability benefits), five years for workers aged 26 to 54 and 10 years for workers aged 55 to 65 .

Lönebidrag, offentligt skyddat arbete (OSA), Utvecklingsanställning and Trygghetsanställning target the unemployed with a reduced capacity to work. Lönebidrag is the dominant programme and has a duration of at most four years. It must be renewed every year. The size of the subsidy depends on the worker's wage and work ability.

\section{Labour market training}

The PES can refer the unemployed, and the employed at risk of becoming unemployed, to labour market training. Vocational training is tailored to the current labour market situation and provided by the PES through various education institutions. Normally, training is not supposed to last more than than six months.

\section{Business start-ups}

A subsidy is given to the unemployed deemed to be in a position to start a business. The subsidy corresponds to the benefits she or he is eligible for. The maximum duration is six months but extensions

1. Work experience placement is classified as an employment incentive scheme in the OECD Labour Market Programmes Database. 


\section{WORKING PAPERS}

The full series of Economics Department Working Papers can be consulted at www.oecd.org/eco/workingpapers/

841. Enhancing the cost-effectiveness of climate change mitigation policies in Sweden (February 2011) by Stéphanie Jamet

840. Policies towards a sustainable use of water in Spain (January 2011) by Andrés Fuentes

839. Increasing public sector efficiency in Slovakia (January 2011) by Felix Hüfner

838. Raising education outcomes in Switzerland (January 2011) by Andrés Fuentes

837. The Price Responsiveness of Housing Supply in OECD Countries (January 2011) by Aida Caldera Sánchez and Åsa Johansson

836. Housing markets and structural policies in OECD countries (January 2011) by Dan Andrews, Aida Caldera Sánchez and Åsa Johansson

835. Raising potential growth after the crisis: A quantitative assessment of the potential gains from various structural reforms in the OECD area and beyond (January 2011) by Romain Bouis and Romain Duval

834. The GDP impact of reform: a simple simulation framework (January 2011) by Sebastian Barnes, Romain Bouis, Philippe Briard, Sean Dougherty and Mehmet Eris

833. Improving the flexibility of the Dutch housing market to enhance labour mobility (January 2011) by Jens Høj

832. Making the Dutch pension system less vulnerable to financial crises (January 2011) by Jens Høj

831. Real house prices in OECD countries: the role of demand shocks and structural policy factors

(December 2010) by Dan Andrews

830. International financial integration and the external positions of euro area countries (December 2010) by Philip R. Lane

829. Improving fiscal performance through fiscal councils (December 2010) by Robert Hagemann 
828. Minimising risks from imbalances in European banking (December 2010) by Sebastian Barnes, Philip Lane and Artur Radziwill

827. Resolving and avoiding unsustainable imbalances (December 2010) by Sebastian Barnes

826. Current account imbalances in the euro area: a comparative perspective (December 2010) by Sebastian Barnes, Jeremy Lawson and Artur Radziwill

825. Does fiscal decentralisation strengthen social capital? Cross-country evidence and the experiences of Brazil and Indonesia

(December 2010) by Luiz de Mello

824. Fiscal decentralisation and public investment: The experience of Latin America (December 2010) by Luiz de Mello

823. Product market regulation and competition in China

(December 2010) by Paul Conway, Richard Herd, Thomas Chalaux, Ping He and Jianxun Yu

822. Reforming China's monetary policy framework to meet domestic objectives (December 2010) by Paul Conway, Richard Herd and Thomas Chalaux

821. Regulatory reforms to unlock long-term growth in Turkey (December 2010) by Rauf Gönenç and Łukasz Rawdanowicz

820. After the crisis: mitigating risks of macroeconomic instability in Turkey (December 2010) by Łukasz Rawdanowicz

819. The 2008-09 crisis in Turkey: performance, policy responses and challenges for sustaining the recovery (December 2010) by Łukasz Rawdanowicz

818. Fiscal-consolidation strategies for Canadian governments (November 2010) by Yvan Guillemette

817. The land transport sector: policy and performance (November 2010) by Jan Persson and Daeho Song

816. A simple model of the relationship between productivity, saving and the current account (November 2010) by Jean-Marc Fournier, Isabell Koske

815. The impact of structural policies on saving, investment and current accounts (November 2010) by Clovis Kerdrain, Isabell Koske, Isabelle Wanner

814. Towards a less distortive and more efficient tax system in Portugal (November 2010) by Alvaro Pina 